\title{
DO DIFFERENCES IN SCHOOL QUALITY GENERATE HETEROGENEITY IN THE CAUSAL RETURNS TO EDUCATION?
}

\author{
Philip DeCicca \\ Harry Krashinsky \\ Working Paper 27089 \\ http://www.nber.org/papers/w27089
NATIONAL BUREAU OF ECONOMIC RESEARCH
1050 Massachusetts Avenue
Cambridge, MA 02138 \\ May 2020
}

We thank Maoyong Fan, Mitchell Hoffman, Erik Nesson, Paul Niekamp, Minh Nguyen, and Phil Oreopoulos for helpful comments. Krashinsky acknowledges funding from the Social Sciences and Humanities Research Council. The views expressed herein are those of the authors and do not necessarily reflect the views of the National Bureau of Economic Research.

NBER working papers are circulated for discussion and comment purposes. They have not been peer-reviewed or been subject to the review by the NBER Board of Directors that accompanies official NBER publications.

(C) 2020 by Philip DeCicca and Harry Krashinsky. All rights reserved. Short sections of text, not to exceed two paragraphs, may be quoted without explicit permission provided that full credit, including (C) notice, is given to the source. 
Do Differences in School Quality Generate Heterogeneity in the Causal Returns to Education? Philip DeCicca and Harry Krashinsky

NBER Working Paper No. 27089

May 2020

JEL No. I26,J24,J38

\begin{abstract}
$\underline{\text { ABSTRACT }}$
Estimating the returns to education remains an active area of research amongst applied economists. Most studies that estimate the causal return to education exploit changes in schooling and/or labor laws to generate exogenous differences in education. An implicit assumption is that more time in school may translate into greater earnings potential. None of these studies, however, explicitly consider the quality of schooling to which impacted students are exposed. To extend this literature, we examine the interaction between school quality and policy-induced returns to schooling, using temporally-available school quality measures from Card and Krueger (1992). We find that additional compulsory schooling, via either schooling or labor laws, increases earnings only if educational inputs are of sufficiently high quality. In particular, we find a consistent role for teacher quality, as measured by relative teacher pay across states, in generating consistently positive returns to compulsory schooling.
\end{abstract}

\author{
Philip DeCicca \\ Ball State University \\ 117 Whitninger Building \\ Muncie, IN 47303 \\ and NBER \\ ppdecicca@bsu.edu \\ Harry Krashinsky \\ Centre for Industrial Relations \\ 121 St. George Street \\ University of Toronto \\ Toronto, ON M5S 2E8 \\ Canada \\ harry.krashinsky@utoronto.ca
}




\section{Introduction}

It is well-established that compulsory schooling and child labor laws (CSLs and CLLs, respectively) increased average schooling levels in the U.S. in the $20^{\text {th }}$ century. Perhaps not surprisingly, a large and growing number of studies have exploited these policy-induced increases in schooling to examine its impact on labor market outcomes like wages and employment, as well as other plausibly impacted outcomes like health and criminal activity. None of these studies, however, have investigated a possible interaction between policy-induced schooling and school quality. That is, none explore whether students induced to complete additional schooling experience returns to that schooling that vary with its quality.

We attempt to fill this gap by exploring the possible interaction between policy-induced returns to schooling and school quality, where the latter is proxied by established measures of school quality taken from the seminal paper by Card and Krueger (1992). In particular, we examine whether and to what extent the estimated monetary returns to schooling vary with the three state-level measures of school quality measures they employ: pupil-teacher ratio, relative teacher salaries, and length of the school term. In principle, the quality of the additional schooling induced by compulsory schooling and/or labor laws may affect human capital accumulation and, hence, the ultimate labor market return to that schooling. Indeed, the existence of such interactive effects hinges on whether these school quality proxies, themselves, have positive impacts on such labor market outcomes. As we will discuss, recent research, particularly with respect to the first two measures, suggests that such interactive effects plausibly exist.

We find evidence that school quality does affect the impact of policy-induced schooling on earnings. We first generate estimates that confirm the findings of Stephens and Yang (2014) which generally suggest there is no effect of policy-induced schooling on labor market earnings using U.S. Census data from 1960 to 1980 on prime-aged males. Building on their main specification, while addressing their general critique, we allow our estimates of the monetary

returns to schooling to vary across higher and lower values of the three school quality proxies in question. While we fail to find consistent evidence of an interactive effect of class size (i.e., pupil to teacher ratio) and average term length (i.e., length of school year), we find strongly bifurcated results for relative teacher pay. In particular, we find consistently positive and 
statistically significant returns to schooling for those students who were educated in a state that paid its teachers more than the state-median relative salary. By contrast, we find consistent evidence of a zero or negative return to schooling for students schooled in states with lower than median relative teacher wages. Overall, our results suggest that returns to compulsory schooling are positive in states with higher than median relative teacher salaries, while no relationship exists in lower than median states, suggesting that school quality, particularly that which may be directly related to teacher quality, may play an important role in the ultimate pecuniary returns to compulsory education.

In the following section, we provide a brief background on research related to the returns to schooling in the United States, as well as reasons why heterogeneity in the three measures of school quality used by Card and Krueger (1992) may affect policy-induced returns to schooling, though our main results focus on relative teacher pay. Section 3 presents our empirical strategy, which follows Stephens and Yang (2014). Section 4 describes our data and presents our findings, which as noted above, suggest that school quality related to teacher pay may increase returns to policy-induced schooling. While we focus on relative teacher pay, we also present analogous estimates associated with pupil to teacher ratio and length of school term. Section 5 briefly concludes the paper.

\section{Background}

\subsection{A very brief overview of the impact of policy-induced returns to education}

Economists have long been interested in the returns to schooling, both theoretically and empirically. On the empirical side, economists have long recognized the statistical difficulties of obtaining valid estimates of the relationship between schooling and earnings. Starting with Angrist and Krueger (1991), the use of two policies--compulsory schooling laws (CSLs) and child labor laws (CLLs)--as instruments for completed schooling gained tremendous popularity to obtain more meaningful estimates of this relationship. Over time, Angrist and Krueger (1991) led to many similar studies, many of which found positive and large financial returns to schooling. ${ }^{1}$

\footnotetext{
${ }^{1}$ Two notable examples are Card (2001) and Oreopoulos (2006). Other early studies such as Lang and Kropp (1986), Acemoglu and Angrist (2000), Black, Devereux and Salvanes (2005) and Goldin and Katz (2011) tended to find a positive relationship between policy-induced schooling and labor market outcomes like earnings, while later,
} 
Recent work by Stephens and Yang (2014) revisits this extensive literature, which has expanded well-beyond labor market outcomes like earnings to outcomes representing health, crime and civic engagement to name a few, and makes a relevant critique. ${ }^{2}$ In particular, Stephens and Yang (2014) show that estimates of the returns to schooling (and other outcomes) in many of these earlier studies are sensitive to the inclusion of school quality measures. More specifically, they show that inclusion of state-level measures of relative teacher pay, pupil to teacher ratio (i.e., class size) and length of the school term from Card and Krueger (1992) results in structural estimates of the relationship between schooling and earnings that are essentially zero, in spite of first stage estimates that imply compulsory schooling laws are valid instruments.

On the face of it, Stephens and Yang (2014) include these variables from Card and Krueger (1992) to account for unobserved school quality. Here, the concern is that unobserved differences in school quality may be correlated with the policy variables that serve as instrumental variables (i.e., hopefully generate quasi-random variation in schooling levels). If so, and if they are omitted from the model, instrument exogeneity is violated. And, indeed, Stephens and Yang (2014) demonstrate the relevant consequences. We take their logic one step further and allow the impact of increases in induced schooling to vary by these school quality measures, as we elaborate on below. In doing so, we believe that we are the first to examine whether policy-induced increases in education depend on the quality of that additional, induced schooling.

2.2 Why school quality might affect policy-induced returns to education?

As noted, it is well-established that compulsory schooling laws and child labor laws have increased average levels of education in the U.S. throughout much of the $20^{\text {th }}$ century. While researchers have exploited these policy-induced increases in schooling to obtain improved estimates of the true return to schooling, no existing work has addressed the possibility that the impact of this additional schooling may depend on its quality. Instead, the literature has essentially treated all additional schooling as uniform, even though that is highly unlikely. The logic of why quality should matter is straightforward: If students are required to spend more

\footnotetext{
particularly non-U.S., studies tended to find decidedly less evidence (c.f., Meghir and Palme, 2005), Pischke and von Wachter (2008), Grenet (2013)).

${ }^{2}$ For an excellent review of work related to the social or non-pecuniary benefits of compulsory law-induced schooling see Oreopoulos and Salvanes (2011).
} 
time in school than originally intended, and if this time is spent in high-quality schooling, then the return to that schooling should tend to be higher than if the required schooling was poor in nature. In other words, since the quality of policy-induced schooling almost certainly varies across place and/or time, heterogeneity in the rate of return to policy-induced schooling is virtually assured. And, although our econometric approach limits us to using state-level measures of school quality, we are able to proxy for it using three variables from Card and Krueger's (1992) seminal paper. In particular, we use their state-level measures of relative teacher pay, pupil to teacher ratio (i.e., class size) and the length of a school year (in days) to proxy for school quality. More precisely, we allow the return to policy-induced schooling to vary across states above and below their median values. ${ }^{3}$ In what follows, we briefly discuss research on each of these three measures, focusing on why we believe they are reasonable proxies for school quality. Ultimately, none of these measures are perfect proxies for school quality, but they are clearly germane to an improved understanding of its impact on estimates of the returns to schooling.

\subsubsection{Relative teacher pay}

Of the three school quality proxies we employ, the most consistent empirical evidence exists for relative teacher pay as a measure of school quality. The gist is that higher relative wages attract higher quality teachers to the classroom. In turn, these higher quality teachers produce students who have learned more, and are subsequently more productive in the labor market. As a result, there are two relevant strands in this literature: one that examines the relationship between teacher pay and teacher quality, and another that examines the relationship between teacher quality and student outcomes, though as noted below there is at least one high quality study that examines the reduced form relationship between teacher compensation and student outcomes. Regarding the first strand, an early study by Murnane and Olson (1989) finds that higher teacher wages, both in absolute and relative terms, increased both entry and duration in the teaching profession. Similarly, Ferguson (1991) and Figlio (1997, 2002) find that higher salaries lead to more qualified teachers entering the teaching profession. Along these lines, Figlio and Rueben (2001) find that tax limit-induced reductions in school spending lead to a

\footnotetext{
${ }^{3}$ The method used to calculate these medians will be described later in the paper.
} 
reduction in the average quality of education majors, as well as new cohorts of public school teachers. Higher relative teacher salaries may also lead to less teacher turnover, which could affect school quality. Hanushek et al. (2004), for example, examine teacher job switching and attrition, and find that while teacher mobility is mainly driven by student characteristics, salary reduces such turnover, albeit modestly. Hanushek and Rivkin (2006) document falling relative teacher salaries in the middle of the twentieth century, and note that "The decline in the relative earnings of teachers has likely led to a fall in average teacher quality of incoming teachers over this period." More recently, Ondrich et al. (2008) find that higher relative teacher salaries reduce teacher attrition. In particular, these authors find that teachers in New York State school districts with higher relative salaries in their county are less likely to leave teaching or switch to a different district within New York State.

So, while the evidence suggests that higher teacher pay leads to higher quality teachers, do higher quality teachers translate into improved student achievement? A large number of studies, using within-school measures of teacher quality, suggest they do. For example, a study by Rockoff (2004), which used administrative panel data from New Jersey, finds that moving up one standard deviation in the teacher fixed effect distribution (i.e., teacher fixed effects are treated as a proxy for unobserved teacher quality) leads to a one-tenth of a standard deviation increase in both reading and math test scores. Similarly, Rivkin et al. (2005), using panel data from Texas schools, find that unobserved teacher quality has substantial impacts on reading and mathematics achievement; indeed, their findings imply that a one standard deviation increase in teacher quality improves student outcomes more than a ten-student reduction in class size. ${ }^{4}$ Measuring quality in a manner similar to the previous two studies, Aaronson et al. (2007) find that teacher quality has similar impacts for a sample of ninth graders in Chicago Public Schools, including particularly large effects for lower-ability students.

More recent studies document a relationship between teacher quality and future outcomes, including wages. Hanushek (2011) uses existing estimates, including those described above, to estimate the impact of within-school teacher quality on labor market productivity. He finds that a one standard deviation increase in teacher quality leads to an annual increase of

\footnotetext{
${ }^{4}$ Similar to Rockoff (2004), this study captures quality that is not directly related to observable characteristics like credentials or experience.
} 
$\$ 400,000$ in the present value lifetime earnings, assuming a fixed class size of twenty. Chetty et al. (2014) find that high valued added (i.e., high quality) teachers improve long-run outcomes with respect to college attendance, teen childbearing and earnings. In particular, these authors find that replacing a teacher in the bottom five percent of their value-added distribution with an average teacher would increase the present value of lifetime earnings by about $\$ 250,000 .^{5}$

As noted, some studies also examine the impact of the reduced form relationship between teacher pay and students outcomes. This is important since the measurement of teacher quality varies across the two literatures described above. ${ }^{6}$ In a well-cited study, Loeb and Page (2000) find that raising teacher wages reduces high school dropout rates. In particular, these authors find that a ten percent increase in teacher wages reduces the dropout rate by nearly four percent. The authors note that mixed results in other related studies is likely due to non-wage characteristics of teaching positions and market-level differences in alternative job opportunities.

\subsubsection{Pupil to teacher ratio}

We next briefly turn to why we believe the pupil-teacher ratio, or class size as the relevant literature refers to it, represents a reasonable proxy for schooling quality. Class size reduction is an intuitive way to increase schooling quality, since more attention from one's teacher should, all else equal, lead to improved student outcomes. That said, since it requires hiring extra teachers, it is very expensive to implement, and there are potential quality issues if the hiring of many new teachers is required, as might be the case with a large-scale initiative to reduce class size. The U.S. literature is somewhat mixed on the impact of class size on student achievement, but tends to find that smaller class sizes lead to improved student outcomes.

The most prominent study of the impacts of class size is the well-known Project STAR randomized experiment from Tennessee. Early research based on Project STAR data found achievement gains on the order of four percentage points the first year selected students experienced substantially smaller classes, and that such test score advantages increased by about

\footnotetext{
${ }^{5}$ For context, this change would represent a 5\% increase relative to average lifetime income, which is a large hypothetical effect, but emblematic of the impact of teacher quality on earnings.

${ }^{6}$ In general, teacher quality in the literature on the impact of teacher pay on teacher quality is measured via process outcomes, like level of schooling and certification status, while it is measured using within-school variation in the literature on the impact of teacher quality on student outcomes.
} 
one percentage point per year after the first year (Krueger, 1999) ${ }^{7}$ In a more recent study, Konstantopolous and Chun (2009) find continued benefits of Project STAR-related class size reductions extending to all socioeconomic groups up until eighth grade, implying the existence of long-run impacts. Most recently, Dynarski, Hyman and Schanzenbach (2013) explore the existence of even longer-run impacts of smaller class sizes via Project STAR. These authors find evidence that those students originally assigned to smaller classrooms had an increased probability of attending and graduating from college, and tended to increase their enrollment in STEM fields, with particularly large effects for black students ${ }^{8}$.

Outside of the experimental, but narrowly tailored, findings from Project STAR, the relevant evidence is more mixed, and includes high quality studies that find no systematic impact of class size on student achievement. In particular, several studies that use yearly fluctuations in population or student enrollment to identify changes in class size find little to no evidence that class size improves student outcomes. In the first study of this type, Hoxby (2000) finds no evidence of class size affecting student achievement and notes that even modest impacts can be ruled out (i.e., the author finds a relatively precisely estimated zero). Using a similar empirical strategy, Rivkin, Hanushek and Kain (2005) and Jepsen and Rivkin (2009) find little evidence of such impacts in Texas and California, respectively. More recently, Chingos (2013), using a different empirical strategy, finds no systematic evidence of beneficial impacts of a state-wide class size reduction program in Florida. Ultimately, the impact of class size on student outcomes is not completely clear, but it appears that Project STAR provides reasonably strong empirical evidence to believe that class size has the potential to increase student achievement. As a result, like Card and Krueger (1992), we consider it to be a potentially reasonable proxy for school quality, although it's possible that the influence of class size within this context may be limited.

\footnotetext{
${ }^{7}$ Class size was reduced by almost half from 20 to 12 students per classroom in this program; results presented later in this study that exploit differences in class size across states do not have similar variation to exploit. Note also that Krueger (1999) found that class size reductions had a larger positive impact for minority children and those receiving subsidized lunches, suggesting that there may be substantial distributional impacts of reducing class size ${ }^{8}$ The authors also address the question of whether such benefits offset the large costs associated with the kind of class size reductions associated with Project STAR and conclude that they likely do not. That said, they also note that the benefits of class size reduction might exceed the costs involved if the program was focused only on the poorest third of students, who saw the largest benefits (i.e., if class size reductions were targeted to this group). While an accurate cost-benefit analysis is crucial in deciding whether class size reduction initiatives are a net social gain, recall that for our purposes we are concerned only with making the case that smaller class sizes may plausibly lead to a higher quality schooling experience.
} 


\subsubsection{Term length}

Finally, we turn to the merits of term length, or length of school year, as a proxy for school quality. Unlike the other two proxies of quality from Card and Kruger (1992) that we employ, research on the length of school year is less common, and generally less rigorous than research on the impacts of teacher compensation and the pupil-teacher ratio. Overall, studies find mixed results on the impact of a state's mandated length of school year on student achievement. For example, while Grogger (1997) and Eide and Showalter (1998) find insignificant effects on student outcomes and subsequent earnings, while Rizzuto and Wachtel (1980) and Betts and Johnson (1997) find a positive impact. For the most part, however, these studies do not employ ostensibly valid research designs_-in particular, they do not account adequately for state level factors that might impart omitted variable bias (e.g., they do not include state fixed effects in their models) so these results may be more suggestive than causal.

Later studies by Lee and Barro (2001) and Woessmann (2003) take a different approach and exploit cross-country differences in school resources, including length of school year. While this approach exploits differences larger than those seen among U.S. states, both of these studies find essentially no impact on student achievement, as measured by standardized test scores. That said, Lavy (2015) takes a similar approach with more recent data and finds that length of school year is positively associated with higher standardized test scores. A more rigorous study by Pischke (2007) uses quasi-experimental variation in length of school year from West Germany. More specifically, the author exploits the mid-1960s "short" school years when the school year in some West German states was reduced by 13 weeks for two school years, or a total of 26 weeks of schooling lost relative to what came before and after. What makes this quasiexperiment so useful for internal validity is that all other elements of the schooling experience were held constant (e.g., curriculum and degree received upon completion). Pischke (2007) finds that, despite its large magnitude, this reduction in length of school year had no impact on long-run employment and earnings, though he finds evidence it increased grade repetition in the elementary school years and led to exposed students being less likely to enroll in higher secondary school tracks. The latter two findings suggest that term length could be a useful measure, but given the relative lack of research and inconsistency in the findings of existing work, we place more weight on the first two measures. 
More generally, while none of these measures are perfect proxies for school quality, the logic for why school quality might matter is sound, and they constitute the best available data on school quality that can be matched to our sample. And, to maintain consistency with the literature, our sample is also used in most relevant work that employs compulsory schooling laws as instrumental variables to examine the relationship between schooling and earnings.

\section{Methodology}

Our regression methodology follows Acemoglu and Angrist (2001) and Stephens and Yang (2014). The analysis will primarily consider the impact of schooling on log weekly earnings, but will also analyze the effect of schooling on additional outcomes. To that end, a two-stage-least squares (2SLS) model will be used, with two different specifications for the second-stage outcome equation. One specification of the second stage will be:

$$
\text { Outcome }_{s t, i}=\alpha E d u c_{s t, i}+\chi_{s}+\delta_{t}+\beta X_{s t, i}+\epsilon_{s t, i}
$$

In this case: $E d u c_{s t, i}$ represents the years of schooling for individual $i$ born in year $t$ in state $s ; \chi_{s}$ and $\delta_{t}$ represent fixed effects for each state-of-birth $s$ and birth-cohort $t$, respectively; and $X_{s t, i}$ represent a set of characteristics for each individual $i$ born in year $t$ in state $s$. Depending on the particular regression used, these characteristics can include: a quartic in age, indicators for census extracts used to create the data, and an indicator for gender. The first-stage equation used for this second-stage model is:

$$
E d u c_{s t, i}=\pi P O L I C Y_{s t}+\lambda_{s}+\theta_{t}+v X_{s t, i}+v_{s t, i}
$$

The variable POLICY st represents either the mandatory schooling laws (CSLs) or child labor laws (CLLs) in state-of-birth $s$ and year-of-birth $t$ depending on the specification. Regarding CSLs, there are a number of different possible instruments to use in this respect, and to remain consistent with prior studies, the main specification will use three indicator variables to represent laws requiring 7, 8 and 9 years of mandatory schooling, which will be represented by the variables RS7, RS8 and RS9, respectively. For CLLs, we follow Acemoglu and Angrist (2001) and parameterize these laws based on the age at which individuals are permitted to leave school for work, as we will discuss in more detail later. 
In addition, this study will also use an alternative specification for the second-stage outcome equation:

$$
\text { Outcome }_{s t, i}=\alpha E_{\text {duc }, i}+\chi_{s}+\delta_{t}+\text { region }_{s} * \delta_{t}+\beta X_{s t, i}+\epsilon_{s t, i}
$$

In this case, region $_{s} * \delta_{t}$ represents the interaction between indicators for the four census regions and the indicators for year-of-birth. ${ }^{9}$ For this particular second-stage model, the related first-stage regression is:

$$
E d u c_{s t, i}=\pi P O L I C Y_{s t}+\lambda_{s}+\theta_{t}+\text { region }_{s} * \theta_{t}+v X_{s t, i}+v_{s t, i}
$$

The last major methodological component to the estimation approach undertaken in this study involves the incorporation of school quality measures. As we have noted, Card and Krueger (1992) compiled multiple measures of school quality for each state-of-birth and year-ofbirth cohort in the data: relative teacher salary, pupil to teacher ratio, and term length. While we believe that the evidence about teacher quality, as measured by relative teacher salaries, is stronger than that related to pupil to teacher ratio and term length, we nevertheless allow the impact of policy-induced increases in formal schooling on weekly earnings to vary by all three measures of school quality.

In particular, we bifurcate our samples using each of the three state-level school quality measures. More specifically, we compute a state-of-birth average for relative teacher salary, pupil-teacher ratio, and term length for all birth cohorts in the sample. These averages are listed in Appendix Tables 1A, 1B and 1C. For each of the three variables, we bifurcate the sample into two roughly equal groups: states whose average value of the school quality variable is greater than the population-weighted median, and states whose average value is less than the populationweighted median. ${ }^{10}$ We estimate 2SLS models for the entire sample, as well as these two subsamples for each measure of school quality. ${ }^{11}$

\footnotetext{
${ }^{9}$ The inclusion of this term represents the major difference between Acemoglu and Angrist (2001) and Stephens and Yang (2014).

${ }^{10}$ For robustness's sake, this study used different methods to bifurcate the states according to average teacher salary. One alternative approach used was dividing the sample by average teacher salary into two equal numbers of states. This resulted in a larger number of observations in the sample of individuals born in states with higher-paid teachers, since these states had larger birth cohorts. Nevertheless, the results from this approach are substantively similar to the results presented in this paper, and are available upon request.

${ }^{11}$ As noted, we will also generate estimates for the other measures of school quality collected by Card and Krueger: pupil-teacher ratios and term length. We follow a similar approach to the one used with teacher salaries, by splitting the states into two groups: those with higher-than-median and lower-than-median measures of the specific school-
} 


\section{Data and Results}

We use data that are identical to those used in Stephens and Yang (2014) and Acemoglu and Angrist (2001). To describe the basic characteristics of these data, Table 1 displays some summary statistics of key variables for certain subsamples within the data. Specifically, the first three columns of Table 1 show summary statistics for white males between the ages of 25 and 54 from the 1960 to 1980 U.S. Censuses. The first column shows sample averages for the entire group of white males in the sample, and the second and third columns show sample averages for the two subsamples of interest: individuals born in states whose average relative teacher salaries are above and below the population-weighted median, respectively. The estimates in the columns demonstrate that individuals born in states with better-paid teachers have higher average log weekly earnings, education and log occupational scores. ${ }^{12}$ In general, the same patterns manifest in the final three columns (that analyze all white respondents between the ages of 25 and 54). ${ }^{13}$ This is broadly suggestive that the educational training and labor market outcomes are generally different for the two samples, which motivates the analysis of the returns to education for these two groups - an explanation for these differences may be that changes in mandatory schooling are more effective when additional mandated schooling time is delivered by better paid and presumably higher quality educators.

The final rows of the table show that a disproportionate number of respondents in the "higher-than-median" subsample are from non-southern states, compared to the "lower-thanmedian” subsample. This is due to the fact that a disproportionate number of southern states have relatively lower teacher salaries. Stephens and Yang (2014) documented the difference in the returns to education for these two geographical areas, so the regression analysis will be replicated with samples of southern and non-southern states to confirm that this geographical difference is not the key factor that drives the results. In addition, the second-last row of the table shows that a larger number of states are present in the "lower-than-median” states in

quality characteristic. The results with these two measures of school quality are broadly similar with the ones presented for teacher salaries, though not consistently so; for the sake of more complete information, we include the corresponding regression in appendix tables, and discuss them in the text below.

${ }^{12}$ Occupational score is a ranking of occupational scores by median earnings in the 1950 Census.

${ }^{13}$ These samples are identical to the ones used in Stephens and Yang (2014) and Acemoglu and Angrist (2001), although Acemoglu and Angrist focus on the subsample of respondents between the ages of 40 and 49. Sample means and regression results for that particular subsample are similar to the ones presented in this paper for the 25 to 54-year-old sample. 
comparison with the "higher-than-median" states; this is due to the fact that states with lower relative teacher salaries also had smaller birth cohorts.

\section{Estimates of the return to schooling by teacher quality}

Table 2 presents the returns to education estimated for the samples described in Table 1. Specifically, Table 2 shows the OLS and 2SLS estimates of $\alpha$ from equations (1) and (3): the effect of an additional year of education on log weekly earnings. Columns (1), (3) and (5) display these estimates from equation (1), which excludes region-by-year-of-birth interactions, and columns (2), (4) and (6) present these estimates from equation (3), which include region-byyear-of-birth interactions. ${ }^{14}$ Together, these first six columns present estimates from the sample of white males aged 25-54. The results in columns (1), (3) and (5) show that in the absence of region-by-year-of-birth interactions, the OLS and 2SLS returns to education are generally similar across the pooled sample, and two bifurcated subsamples. The OLS return is typical in its magnitude, and the Moreira confidence intervals listed beneath the 2SLS estimates of $\alpha$ do not include zero, which indicate a statistically significant effect of education. Furthermore, the first stage of the 2SLS estimate is similar, too - the coefficients on RS7, RS8, and RS9 are generally increasing in magnitude, and the F-test of their joint significance is above any reasonable threshold to detect weak instruments.

However, different results are present in columns (2), (4) and (6), once region-by-yearof-birth interactions are included in the model. As with Stephens and Yang (2014), the coefficient on the 2SLS estimate of $\alpha$ in column (2) is small in magnitude, and its confidence interval indicates that it is not possible to reject a zero return to education in this case. But this result is different once the bifurcated samples are considered. Individuals born in states with better-paid teachers do not exhibit a similar 2SLS return to education - for these states, the 2SLS estimate of $\alpha$ in column (4) is approximately seven percent, and its confidence interval rejects the hypothesis that this estimate is zero. Furthermore, the first stage regression is generally supportive that the mandatory schooling laws are effectual, too - the coefficients on the RS7, RS8, and RS9 are increasing in magnitude, and the F-test of their joint significance rejects the

\footnotetext{
${ }^{14}$ In this case, the variable $\mathrm{X}_{\mathrm{st}, \mathrm{i}}$ does not include any variables - therefore, year-of-birth and state-of-birth indicators are the only other right-hand-side variables in these regressions.
} 
hypothesis that they are weak instruments. Indeed, the F-statistic is over double that of the pooled sample.

By contrast, the results in column (6) suggest that the inclusion of region-by-year-of-birth interactions for states of birth with less-well-paid teachers indicate that changes in mandatory schooling laws are not effectual policies for either changing overall educational attainment or enhancing labor market earnings. In these states, the first-stage regression exhibits coefficients on RS7, RS8, and RS9 that are not increasing in magnitude, as would be expected, and the F-test of their joint significance reveals an F-statistic that is indicative of a weak instrument. The resulting second stage estimates of $\alpha$ from equation (3) is similar in magnitude to that of equation (1) for this subsample, but is accompanied by a sufficiently wide confidence interval that does not permit a zero effect to be rejected.

Our estimate in column (2), which is consistent with the corresponding one in Stephens and Yang (2014), suggests that changes in mandatory schooling laws were ineffectual in improving earnings for individuals in our overall sample, but this masks an underlying heterogeneity in the returns to education. Rather, our findings imply that these laws are ineffectual for individuals in states that pay their teachers relatively lower salaries. By contrast, individuals born in states that pay their teachers relatively higher salaries exhibit positive and significant 2SLS estimates of the return to education, regardless of the inclusion of region-byyear-of-birth indicators. In particular, we estimate that the return to an additional year of schooling is just over seven percent. This pattern suggests that merely changing laws to force students to obtain more education does not unconditionally improve labor market outcomes; instead, students who are required to obtain more education in states with higher-paid (and perhaps higher-skilled) teachers benefit from the additional educational training they receive. ${ }^{15}$

The final six columns of Table 2 display the same estimates for the larger sample of all whites between the ages of 25 and 54, and a similar pattern is evident with this sample as was

\footnotetext{
${ }^{15}$ Of course, it can also be argued that the changes in the mandatory schooling laws are not binding in the states with relatively lower teacher salaries, and this is an alternative explanation for this finding. In larger samples discussed later on, it will be demonstrated that the first-stage is more robust in these states, but similarly small 2SLS estimates still persist in these cases. This suggests that relative teacher pay is primary cause of this difference, not nonbinding laws.
} 
exhibited in the first six columns of the table. ${ }^{16}$ Columns (7) and (8) demonstrate that the 2SLS estimate of $\alpha$ for the pooled sample is positive and statistically significant when the framework excludes region-by-year-of-birth interactions, but $\alpha$ is small and statistically insignificant when the model includes these interactions, as in Stephens and Yang (2014). And although this pattern is mirrored in columns (11) and (12) for the subsample drawn from states with teachers paid relatively lower salaries, no such pattern is evident in columns (9) and (10), for the subsample drawn from states with teachers paid relatively higher salaries. Indeed, inclusion of these interactions reduces the implied return to schooling from 8.2 percent to 6.8 percent, but the latter estimate remains precisely estimated, and is similar to the estimate of 7.4 percent for our corresponding sample of similarly-aged white males. So, again, our estimates imply a heterogeneity in the returns to education: CSL-induced increases in education in states with relatively high teacher pay has systematically positive returns, while this return is not evident in states with relatively lower teacher pay.

\section{Further Refinements}

Estimates in Table 3 refine our Table 2 estimates even further. The first six columns of Table 3 exhibit the estimates of $\alpha$ that are drawn only from equation (3) - that include region-byyear-of-birth interactions - but are subdivided within each sample by southern and non-southern states. Columns (1) and (2) show that for both southern and non-southern states in the pooled sample, 2SLS estimates of $\alpha$ are still small in magnitude and not statistically different than zero. But the same pattern evident for the "higher-than-median” subsample is also evident in columns (3) and (4) for both the southern and non-southern states within this subsample. Both sets of states exhibit positive and statistically significant 2SLS estimates of the return to education, and their first stages both have acceptably high F-statistics, and gradually increasing coefficients on RS7, RS8 and RS9. The "lower-than-median” subsample, however, shows the same pattern in columns (5) and (6) with one notable difference: although the 2SLS estimates of the return to education are not statistically different than zero (in the non-southern states of birth) or negative (in the southern states), it is notable that the first stage for the non-southern subsample is relatively strong. The F-statistic testing the joint significance of the coefficients is well above

\footnotetext{
${ }^{16}$ In this case, the variable $\mathrm{X}_{\mathrm{st}, \mathrm{i}}$ includes a quartic in age, as well as two indicator variables for the Census extract from which the data was collected.
} 
any reasonable threshold for rejecting the instruments as weak. This is important because it serves as evidence to differentiate two potential explanations for the low returns to schooling in the “lower-than-median” subsample: non-binding changes in mandatory schooling laws (which would result in insignificant returns to schooling) and lower-salaried teachers, who may not be as adept at training students as their better-paid counterparts. In column (5), the first stage Fstatistic shows that the mandatory schooling laws are clearly binding in non-southern states, but the extra educational training imparted by these laws does not have a significant effect on earnings for students.

Taken together, our results suggest that although regional effects are clearly important within this framework, it is also critical to consider heterogeneity in the returns to education, and whether the quality of the education which students are compelled to complete when assessing its ultimate impact on outcomes of interest like the wage rate. Indeed, as we have documented, states with better-paid teachers appear to exhibit positive and statistically significant 2SLS returns to education, while there is much less evidence of an effect in states with less-well-paid teachers.

In the last six columns of Table 3, the model is re-estimated for individuals who reside in their states of birth ("non-migrants”) and those who do not ("migrants”) to address the potential concern about bias being introduced by systematic differences in migration patterns between the subsamples used in the paper. Since migration is endogenous, and may be partly caused by local economic opportunities, a possible concern is that the "higher-than-median" and "lower-thanmedian" subsamples have different opportunities in this regard, and this difference may generate the variation in the estimates of $\alpha$ for these two subsamples. The last six columns of Table 3 suggest that this is not the case. Columns (7) and (8) show that non-migrants in the pooled sample have a small negative, but statistically significant return to education, while migrants have a significantly positive return to education. The implication of these results becomes clearer when considering the final four columns: in columns (9) and (10), individuals in the "higher-than-median" subsample exhibit positive and statistically significant returns to education, regardless of whether or not they still reside in their state of birth. This suggests that the positive returns to education documented for this subsample throughout our analyses are not generated exclusively by migration choices. Although migrants appear to have somewhat larger 
returns to education than non-migrants, non-migrants appear to obtain more education due to compulsory schooling laws, which appears, in turn, to raise their earnings. By contrast, the “lower-than-median” subsample estimates in columns (11) and (12) suggest that non-migrants are not deriving a benefit from CSL-induced education. Given the acceptably large F-statistic of the first stage, it would appear that changes in compulsory schooling laws force this group to obtain more education, but given that it is acquired from teachers with relatively lower salaries, they don't appear to benefit from this extra training. In fact, the estimates are negative and statistically different than zero for this group.

\section{Additional estimates and robustness checks}

In addition to examining wage outcomes, Table 4 examines the impact of education on other labor market indicators, as well as non-market outcomes. As was the case with Table 2, Table 4 presents a comparison of OLS and 2SLS estimates of the effect of education on various outcomes, but for brevity's sake, only one set of 2SLS estimates are presented: those corresponding to the specification in equation (3) along with controls for school quality. The first row of the table shows the result that has been documented in the earlier tables: the inclusion of region-by-year-of-birth interactions yields 2SLS estimates of the effect of education on earnings that are not statistically different from zero for the pooled sample, but heterogeneity in the effect of education is evident for the lower-than-median and the higher-than-median subsamples. This effect is mirrored in row 2, which uses the log occupational score as the outcome measure within the regression, and the next four rows demonstrate that the differential effect of education on labor market outcomes for the two subsamples is not due to differences in its effect on unemployment, marital status, or institutionalization.

As a robustness check of the results in Tables 2 and 3, the analysis also uses the child labor instruments constructed by Angrist and Acemoglu (2001) in lieu of compulsory schooling ages. Corresponding results are presented in Appendix Tables 2 and 3. These instruments are defined as larger of two possible values: (i) the difference between the age at which an individual may first receive a work permit and the age at which they must enrol in school, and (ii) the education required to obtain a work permit. These instruments are meant to capture the minimum amount of schooling an individual can obtain before entering the workforce, and for the purpose of this study, these instruments will be represented by three indicator variables that 
represent laws requiring 7, 8 and 9 years of schooling before work is possible, which will be represented by the variables CL7, CL8 and CL9, respectively.

For brevity's sake, Appendix Table 2 displays only the 2SLS results from this framework, and the findings are generally consistent with those in Table 2. In the pooled sample, the 2SLS estimates of the return to education are statistically different from zero when the framework does not include region-by-year-of-birth interactions, but is not statistically different from zero when these interactions are included in the framework. This is true in columns (1) and (2) for white males between the ages of 25 and 54, and in columns (7) and (8) for white males and females in the same age range. But as was the case with compulsory schooling laws, it is also true that there is a different return to education for the two subsamples divided by relative teacher pay. For the "higher-than-median" subsample in columns (3) \& (4), and (9) \& (10), the 2SLS estimates of the return to education are uniformly statistically different from zero, and the first stage in all cases has acceptably large F-statistics to reject the notion that the child labor indicators are weak instruments. The "lower-than-median" subsample also exhibits the pattern that is evident in earlier tables. In columns (5) \& (6), and (11) \& (12), the inclusion of region-by-year-of-birth interactions in the specification changes the 2SLS estimates of the return to education from statistically significant to not statistically different than zero. This occurs despite the fact that the first stages in all four columns have reasonably high Fstatistics, suggesting that a lack of enforcement of these laws is not the prime reason for the statistical insignificance of the second-stage estimates.

Appendix Table 3 examines the robustness of these findings by replicating the analysis with samples of southern and non-southern states, as well as "non-migrants" and "migrants". In all cases, Appendix Table 3 only includes 2SLS results from models which include region-byyear-of-birth interactions (i.e., equations (3) and (4)). The first two columns of the table show that the 2SLS estimates of the return to education are not statistically different than zero for the pooled sample in both southern and non-southern states. But the "higher-than-median" and "lower-than-median" subsamples exhibit - again - different estimates. The "higher-thanmedian" subsample has estimates of the return to education that are statistically different than zero in both sets of states, whereas the "lower-than-median" subsample has estimates of the return to education that are not statistically different than zero (or even negative) for both sets of 
states. So, again, it appears that school quality, at least that which operates through teachers, plays an important role beyond that of any regional differences, and underpins heterogeneity in the returns to education.

In the last six columns of Appendix Table 3, estimates by “migrant” and "non-migrant” status mimic those shown in Table 3. Columns (7) and (8) show that non-migrants in the pooled sample have a small negative, but statistically significant return to education, while migrants have a significantly positive return to education. Again, individuals in the "higher-than-median" subsample exhibit positive and statistically significant returns to education, regardless of whether or not they reside in their state of birth (i.e., in columns (9) and (10)). This again suggests that the positive returns to education documented for this subsample in other cases are not due to positive returns being extracted from migration choices. Although migrants appear to have a somewhat larger return to education than non-migrants, non-migrants also appear to obtain more education when child labor laws tighten, and the resulting increase in education appears to raise their earnings. By contrast, the "lower-than-median” subsample estimates in columns (11) and (12) suggest that non-migrants are not deriving a benefit from education. Given the acceptably large F-statistic of the first stage, it again appears that changes in child labor laws force this group to obtain more education, but they don't appear to benefit from this extra training since, as in Table 3, the estimates are negative and statistically different than zero for this group.

\section{Other measures of School Quality}

Appendix Tables 4 through 7 present OLS and two-stage-least squares for samples that are divided by states that have higher-than-median and lower-than-median term lengths and pupil-teacher ratios. In Appendix Tables 4 and 5, the states are split by term length ${ }^{17}$, and the results are generally consistent with the results in Tables 2 and 3 using both the "required schooling” instruments and the "child labor” instruments. In columns 4 and 10 in both Appendix tables, it is evident that states with higher-than-median instructional days in a year have positive and (mostly) statistically significant 2SLS returns to education when regional trends are included

\footnotetext{
${ }^{17}$ In this case, states were split according to those with more than 178 instructional days (on average) during the school year, and those with less than 178 instructional days (on average).
} 
in the regression, while columns 6 and 12 in both Appendix tables show that those with lowerthan-median instructional days do not have statistically significant 2SLS returns to education. In Appendix Tables 6 and 7, the states are split by pupil-teacher ratios ${ }^{18}$, and the results demonstrate that bifurcating by this measure has little effect on the 2SLS results; in both subsamples, the 2SLS findings are not statistically significant, both with and without regional trends. This result may be evident because of the relatively small variation in average pupilteacher ratios across states; the average pupil-teacher ratio in the lower-than-median subsample is 24.6, while the equivalent measure is 28.8 in the higher-than-median subsample. Prior studies have suggested that relatively small changes in this measure need not have a significant effect on student achievement, and this notion is consistent with these findings here, as well.

\section{Conclusions}

In this paper, we explored a new interaction between policy-induced returns to schooling (i.e., that which are induced by either compulsory schooling laws or child labor laws) and school quality. While the logic is clear-the impact of policy-induced increases in schooling should affect its return —we believe that we are the first to investigate the interactive impact of school quality on the return to education. While we fail to find consistent evidence of an interactive effect of class size and term length, we find consistently strong evidence for such impacts of relative teacher pay. More precisely, we find consistently positive and statistically significant returns to schooling for those students who were educated in a state that paid its teachers more than the state-median relative salary. In contrast, we find consistent evidence of a zero or negative return to schooling for students schooled in states with lower than median relative teacher wages.

Our results imply that school quality, particularly that which is plausibly related to teacher quality, may play an important role in the ultimate pecuniary returns to additional policyinduced education. In other words, school quality may well give rise to heterogeneity in the returns to additional policy-induced education. Furthermore, these results have strong implications for several strands of empirical literatures that have assumed a homogeneous, causal return to education as a mechanism for examining other relationships in economics. Aside from

\footnotetext{
${ }^{18}$ In this case, states were split according to those whose average pupil-teacher ratio is less than 26.8, and those whose average pupil-teacher ratio is greater than 26.8 .
} 
labor economics, studies in health economics, crime, and political economy all implement models that exploit universally positive returns to education that now need to be reconsidered in light of these findings. 
Table 1: Summary Statistics

\begin{tabular}{|c|c|c|c|c|c|c|}
\hline & \multicolumn{3}{|c|}{ White Males Ages 25-54 } & \multicolumn{3}{|c|}{ All Whites Ages 25-54 } \\
\hline & $\begin{array}{l}\text { Pooled } \\
\text { Sample }\end{array}$ & $\begin{array}{l}\text { Higher } \\
\text { than } \\
\text { Median }\end{array}$ & $\begin{array}{c}\text { Lower } \\
\text { than } \\
\text { Median }\end{array}$ & $\begin{array}{l}\text { Pooled } \\
\text { Sample }\end{array}$ & $\begin{array}{l}\text { Higher } \\
\text { than } \\
\text { Median }\end{array}$ & $\begin{array}{c}\text { Lower } \\
\text { than } \\
\text { Median }\end{array}$ \\
\hline $\begin{array}{l}\text { Log Weekly } \\
\text { Earnings }\end{array}$ & $\begin{array}{c}5.501 \\
(0.793)\end{array}$ & $\begin{array}{c}5.541 \\
(0.770)\end{array}$ & $\begin{array}{c}5.454 \\
(0.818)\end{array}$ & $\begin{array}{c}5.214 \\
(0.896)\end{array}$ & $\begin{array}{c}5.250 \\
(0.884)\end{array}$ & $\begin{array}{c}5.172 \\
(0.909)\end{array}$ \\
\hline Education & $\begin{array}{c}12.54 \\
(3.007)\end{array}$ & $\begin{array}{c}12.83 \\
(2.841)\end{array}$ & $\begin{array}{l}12.19 \\
(3.158)\end{array}$ & $\begin{array}{c}12.53 \\
(2.824)\end{array}$ & $\begin{array}{c}12.78 \\
(2.691)\end{array}$ & $\begin{array}{c}12.23 \\
(2.946)\end{array}$ \\
\hline $\begin{array}{c}\text { Log Occupational } \\
\text { Score }\end{array}$ & $\begin{array}{c}3.350 \\
(0.331)\end{array}$ & $\begin{array}{c}3.365 \\
(0.326)\end{array}$ & $\begin{array}{c}3.333 \\
(0.336)\end{array}$ & $\begin{array}{c}3.258 \\
(0.349)\end{array}$ & $\begin{array}{c}3.271 \\
(0.346)\end{array}$ & $\begin{array}{c}3.242 \\
(0.353)\end{array}$ \\
\hline Divorced & $\begin{array}{c}0.059 \\
(0.236)\end{array}$ & $\begin{array}{c}0.059 \\
(0.235)\end{array}$ & $\begin{array}{c}0.060 \\
(0.237)\end{array}$ & $\begin{array}{c}0.082 \\
(0.275)\end{array}$ & $\begin{array}{c}0.082 \\
(0.274)\end{array}$ & $\begin{array}{c}0.083 \\
(0.276)\end{array}$ \\
\hline Unemployed & $\begin{array}{c}0.036 \\
(0.186)\end{array}$ & $\begin{array}{c}0.035 \\
(0.184)\end{array}$ & $\begin{array}{c}0.037 \\
(0.188)\end{array}$ & $\begin{array}{c}0.034 \\
(0.182)\end{array}$ & $\begin{array}{c}0.034 \\
(0.182)\end{array}$ & $\begin{array}{c}0.035 \\
(0.183)\end{array}$ \\
\hline $\begin{array}{l}\text { Percent born in } \\
\text { Southern State }\end{array}$ & $\begin{array}{c}0.302 \\
(0.459)\end{array}$ & $\begin{array}{c}0.102 \\
(0.303)\end{array}$ & $\begin{array}{c}0.538 \\
(0.499)\end{array}$ & $\begin{array}{c}0.303 \\
(0.459)\end{array}$ & $\begin{array}{c}0.106 \\
(0.307)\end{array}$ & $\begin{array}{c}0.535 \\
(0.499)\end{array}$ \\
\hline $\begin{array}{c}\text { Number of States } \\
\text { of Birth }\end{array}$ & 49 & 21 & 28 & 49 & 21 & 28 \\
\hline Observations & $2,166,387$ & $1,174,871$ & 991,516 & $3,680,223$ & $1,992,397$ & $1,687,826$ \\
\hline
\end{tabular}

Notes: The data are drawn from the U.S. Census extracts from 1960, 1970 and 1980; the gender, race and age range of the subsamples are defined in the first row of the table. Columns entitled "pooled sample" include all observations in the sample; columns entitled "Higher than Median" use individuals born in states with relative average teacher salaries above the population-weighted median; columns entitled "Lower than Median" use individuals born in states with relative average teacher salaries below the population-weighted median. Specific states in the "Higher than Median" and "Lower than Median" subsamples (and the relative average teacher salaries paid in each state) are specified in Appendix Table 1 . 
Table 2: Comparison of OLS and 2SLS Estimates of the Returns to Schooling for Pooled Sample and Subsamples Divided by Teacher Pay

\begin{tabular}{|c|c|c|c|c|c|c|c|c|c|c|c|c|}
\hline & \multicolumn{6}{|c|}{ White Males Ages 25-54 } & \multicolumn{6}{|c|}{ All Whites Ages 25-54 } \\
\hline & \multicolumn{2}{|c|}{ Pooled } & \multicolumn{2}{|c|}{ Higher than Median } & \multicolumn{2}{|c|}{$\begin{array}{l}\text { Lower than } \\
\text { Median }\end{array}$} & \multicolumn{2}{|c|}{ Pooled } & \multicolumn{2}{|c|}{ Higher than Median } & \multicolumn{2}{|c|}{ Lower than Median } \\
\hline & (1) & $(2)$ & (3) & $(4)$ & (5) & (6) & $(7)$ & (8) & (9) & (10) & (11) & (12) \\
\hline OLS & $\begin{array}{c}0.063 \\
(0.0004)\end{array}$ & $\begin{array}{c}0.063 \\
(0.0004)\end{array}$ & $\begin{array}{c}0.062 \\
(0.0006)\end{array}$ & $\begin{array}{c}0.062 \\
(0.0006)\end{array}$ & $\begin{array}{c}0.064 \\
(0.0004)\end{array}$ & $\begin{array}{c}0.064 \\
(0.0004)\end{array}$ & $\begin{array}{c}0.068 \\
(0.0003)\end{array}$ & $\begin{array}{c}0.068 \\
(0.0003)\end{array}$ & $\begin{array}{c}0.067 \\
(0.0004)\end{array}$ & $\begin{array}{c}0.067 \\
(0.0004)\end{array}$ & $\begin{array}{c}0.069 \\
(0.0003)\end{array}$ & $\begin{array}{c}0.069 \\
(0.0003)\end{array}$ \\
\hline 2SLS & $\begin{array}{c}0.097 \\
{[0.080,} \\
0.117]\end{array}$ & $\begin{array}{c}-0.014 \\
{[-0.066} \\
0.021]\end{array}$ & $\begin{array}{c}0.086 \\
{[0.068,} \\
0.106]\end{array}$ & $\begin{array}{c}0.074 \\
{[0.051,} \\
0.096]\end{array}$ & $\begin{array}{r}0.103 \\
{[0.059} \\
0.152]\end{array}$ & $\begin{array}{c}-0.113 \\
{[-0.400} \\
0.066]\end{array}$ & $\begin{array}{c}0.105 \\
{[0.083,} \\
0.123]\end{array}$ & $\begin{array}{c}-0.003 \\
{[-0.058} \\
0.016]\end{array}$ & $\begin{array}{c}0.082 \\
{[0.059,} \\
0.096]\end{array}$ & $\begin{array}{c}0.068 \\
{[0.043,} \\
0.084]\end{array}$ & $\begin{array}{c}0.143 \\
{[0.110,} \\
0.193]\end{array}$ & $\begin{array}{c}-0.072 \\
{[-0.180} \\
0.036]\end{array}$ \\
\hline $\begin{array}{l}\text { First } \\
\text { Stage }\end{array}$ & & & & & & & & & & & & \\
\hline RS7 & $\begin{array}{c}0.097 \\
(0.036)\end{array}$ & $\begin{array}{c}0.047 \\
(0.027)\end{array}$ & $\begin{array}{c}0.203 \\
(0.060)\end{array}$ & $\begin{array}{c}0.018 \\
(0.040)\end{array}$ & $\begin{array}{c}0.059 \\
(0.037)\end{array}$ & $\begin{array}{c}0.082 \\
(0.035)\end{array}$ & $\begin{array}{c}0.079 \\
(0.033)\end{array}$ & $\begin{array}{c}0.029 \\
(0.022)\end{array}$ & $\begin{array}{c}0.247 \\
(0.055)\end{array}$ & $\begin{array}{c}0.016 \\
(0.033)\end{array}$ & $\begin{array}{c}0.031 \\
(0.030)\end{array}$ & $\begin{array}{c}0.061 \\
(0.028)\end{array}$ \\
\hline RS8 & $\begin{array}{c}0.268 \\
(0.028)\end{array}$ & $\begin{array}{c}0.135 \\
(0.024)\end{array}$ & $\begin{array}{c}0.424 \\
(0.044)\end{array}$ & $\begin{array}{c}0.273 \\
(0.037)\end{array}$ & $\begin{array}{c}0.222 \\
(0.032)\end{array}$ & $\begin{array}{c}0.067 \\
(0.032)\end{array}$ & $\begin{array}{c}0.246 \\
(0.026)\end{array}$ & $\begin{array}{c}0.136 \\
(0.019)\end{array}$ & $\begin{array}{c}0.437 \\
(0.038)\end{array}$ & $\begin{array}{c}0.257 \\
(0.029)\end{array}$ & $\begin{array}{c}0.188 \\
(0.026)\end{array}$ & $\begin{array}{c}0.079 \\
(0.025)\end{array}$ \\
\hline RS9 & $\begin{array}{c}0.449 \\
(0.033)\end{array}$ & $\begin{array}{c}0.217 \\
(0.029)\end{array}$ & $\begin{array}{c}0.656 \\
(0.057)\end{array}$ & $\begin{array}{c}0.457 \\
(0.049)\end{array}$ & $\begin{array}{c}0.285 \\
(0.034)\end{array}$ & $\begin{array}{c}0.076 \\
(0.034)\end{array}$ & $\begin{array}{c}0.406 \\
(0.028)\end{array}$ & $\begin{array}{c}0.222 \\
(0.023)\end{array}$ & $\begin{array}{c}0.668 \\
(0.050)\end{array}$ & $\begin{array}{c}0.434 \\
(0.041)\end{array}$ & $\begin{array}{c}0.252 \\
(0.028)\end{array}$ & $\begin{array}{c}0.096 \\
(0.026)\end{array}$ \\
\hline F-test & 81.4 & 23.6 & 61.7 & 51.0 & 30.4 & 2.4 & 91.7 & 40.6 & 75.2 & 60.9 & 38.0 & 4.7 \\
\hline $\mathrm{N}$ & $2,166,387$ & $2,166,387$ & $1,174,871$ & $1,174,871$ & 991,516 & 991,516 & $3,680,223$ & $3,680,223$ & $1,992,397$ & $1,992,397$ & $1,687,826$ & $1,687,826$ \\
\hline
\end{tabular}

Notes: The data use the U.S. Census extracts from 1960, 1970 and 1980. The estimates in columns (1) to (6) use a sample of white males aged 40 to 49, and the estimates in columns (7) to (12) use a sample of white males aged 25 to 54 . The estimates in columns (3), (4), (9) and (10) are derived from individuals born in states whose average teacher pay is above the population-weighted median value, and the estimates in columns (5), (6), (11) and (12) are derived individuals born in states whose average teacher pay is below the population-weighted median value. OLS and 2SLS estimates of the returns to schooling are in the first two rows of the table, and the Moreira confidence interval for the 2SLS estimates are listed in brackets underneath the 2SLS estimates. The key instruments used in the first stage regression are three required schooling dummies, indicating seven, eight or nine years of required schooling in a state for a particular birth cohort; these coefficients are listed in the rows entitled RS7, RS8 and RS9. All regressions include year-of-birth and state-of-birth indicator variables, and estimates in even-numbered columns also contain region-by-year-of-birth indicator variables. 
Table 3: Comparison of OLS and 2SLS Estimates of the Returns to Schooling for the Pooled Sample and Subsamples Divided by Teacher Pay

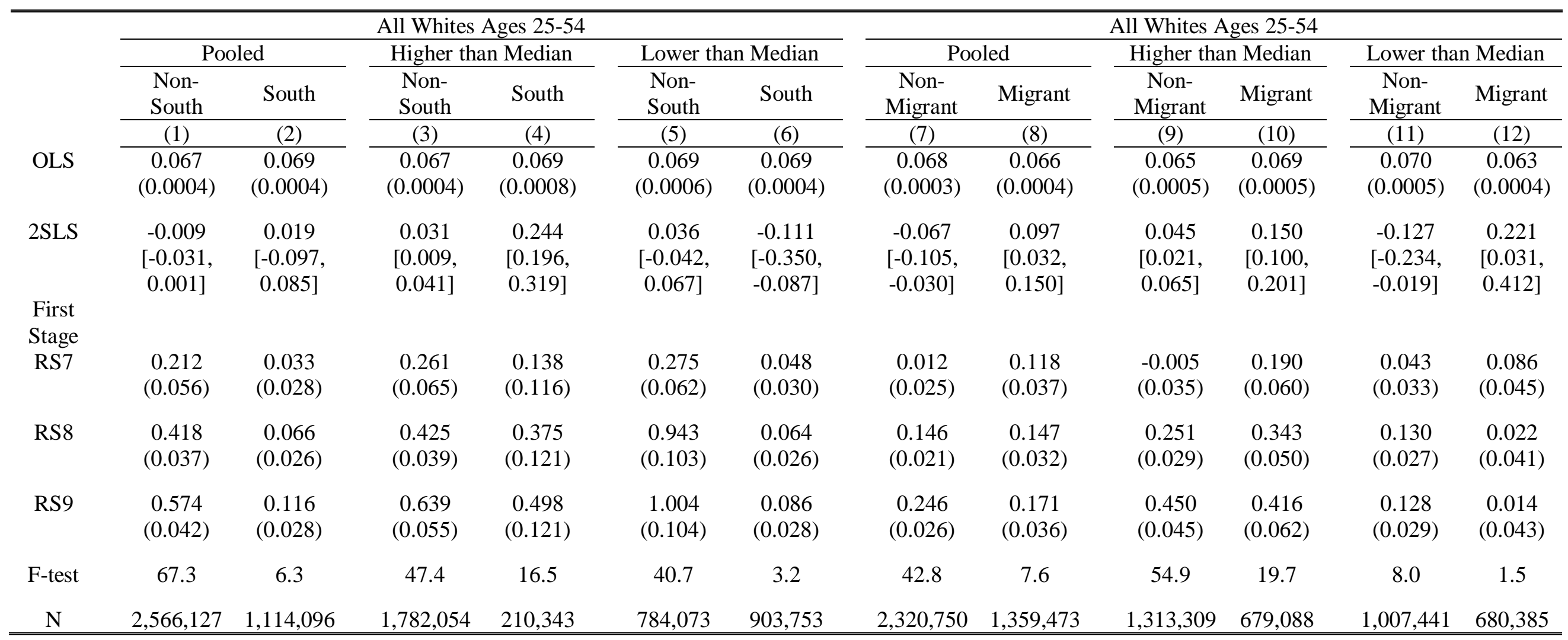

Notes: The data use a sample of white males and females aged 25 to 54 from the 1960, 1970 and 1980 U.S. Census extracts. Estimates in columns (7), (9) and (11) use a subsample of respondents from southern states; the estimates in columns (8), (10) and (12) use a subsample of respondents from non-southern states. The estimates in columns (3), (4), (9) and (10) are derived from individuals born in states whose average teacher pay is above the population-weighted median value, and the estimates in columns (5), (6), (11) and (12) are derived individuals born in states whose average teacher pay is below the population-weighted median value. OLS and 2SLS estimates of the returns to schooling are in the first two rows of the table, and the Moreira confidence interval for the 2SLS estimates are listed in brackets underneath the 2SLS estimates. The key instruments used in the first stage regression are three required schooling dummies, indicating seven, eight or nine years of required schooling in a state for a particular birth cohort; these coefficients are listed in the rows entitled RS7, RS8 and RS9. All regressions include year-of-birth and state-of-birth indicator variables, and estimates in columns (2), (4), (6), and (7) through (12) also contain region-by-year-of-birth indicator variables. 
Table 4: Comparison of OLS and 2SLS Estimates of the Effect of Schooling on Additional Outcomes for the Pooled Sample and Subsamples Divided by Teacher Pay

\begin{tabular}{|c|c|c|c|c|c|c|}
\hline \multirow[b]{2}{*}{ White males ages 25-54: } & \multicolumn{2}{|c|}{ Pooled } & \multicolumn{2}{|c|}{ Higher than Median } & \multicolumn{2}{|c|}{ Lower than Median } \\
\hline & $\begin{array}{c}(1) \\
\text { OLS }\end{array}$ & $\begin{array}{c}(2) \\
\text { 2SLS }\end{array}$ & $\begin{array}{c}\text { (3) } \\
\text { OLS }\end{array}$ & $\begin{array}{c}(4) \\
\text { 2SLS }\end{array}$ & $\begin{array}{c}\text { (5) } \\
\text { OLS }\end{array}$ & $\begin{array}{c}(6) \\
\text { 2SLS }\end{array}$ \\
\hline $\begin{array}{c}\text { Log weekly wage } \\
{[(1) \&(2) \text { mean }=5.21} \\
\text { (3) \& (4) mean }=5.26 \\
\text { (5) \& (6) mean }=5.15]\end{array}$ & $\begin{array}{c}0.063 \\
(0.0004)\end{array}$ & $\begin{array}{c}-0.014 \\
{[-0.066} \\
0.021]\end{array}$ & $\begin{array}{c}0.062 \\
(0.0006)\end{array}$ & $\begin{array}{r}0.074 \\
{[0.051} \\
0.096]\end{array}$ & $\begin{array}{c}0.064 \\
(0.0004)\end{array}$ & $\begin{array}{c}-0.113 \\
{[-0.291} \\
0.066]\end{array}$ \\
\hline $\begin{array}{l}\text { Log occupational score } \\
\text { [(1) \& (2) mean }=3.34 \\
(3) \&(4) \text { mean }=3.36 \\
\text { (5) \& (6) mean }=3.32]\end{array}$ & $\begin{array}{c}0.036 \\
(0.0002)\end{array}$ & $\begin{array}{c}-0.0011 \\
{[-0.023} \\
0.017]\end{array}$ & $\begin{array}{c}0.038 \\
(0.0002)\end{array}$ & $\begin{array}{r}0.034 \\
{[0.024} \\
0.046]\end{array}$ & $\begin{array}{c}0.035 \\
(0.0002)\end{array}$ & $\begin{array}{c}-0.040 \\
{[-0.121} \\
0.041]\end{array}$ \\
\hline $\begin{array}{c}\text { Unemployed } \\
{[(1) \&(2) \text { mean }=0.033} \\
\text { (3) \& (4) mean }=0.032 \\
\text { (5) \& (6) mean }=0.033]\end{array}$ & $\begin{array}{c}-0.005 \\
(0.00007)\end{array}$ & $\begin{array}{c}0.0003 \\
{[-0.0062} \\
0.0132]\end{array}$ & $\begin{array}{c}-0.005 \\
(0.0001)\end{array}$ & $\begin{array}{r}-0.009 \\
{[-0.014} \\
-0.002]\end{array}$ & $\begin{array}{c}-0.005 \\
(0.0001)\end{array}$ & $\begin{array}{c}-0.007 \\
{[-0.049} \\
0.034]\end{array}$ \\
\hline $\begin{array}{c}\text { Divorced } \\
{[(1) \&(2) \text { mean }=0.047} \\
(3) \&(4) \text { mean }=0.046 \\
\text { (5) \& (6) mean }=0.048]\end{array}$ & $\begin{array}{c}-0.0018 \\
(0.00006)\end{array}$ & $\begin{array}{c}-0.0063 \\
{[-0.0175} \\
0.0036]\end{array}$ & $\begin{array}{c}-0.002 \\
(0.00009)\end{array}$ & $\begin{array}{r}-0.012 \\
{[-0.019} \\
-0.007]\end{array}$ & $\begin{array}{c}-0.001 \\
(0.00008)\end{array}$ & $\begin{array}{c}0.062 \\
{[-0.010} \\
0.133]\end{array}$ \\
\hline $\begin{array}{c}\text { In mental institution } \\
{[(1) \&(2) \text { mean }=0.003} \\
(3) \&(4) \text { mean }=0.003 \\
\text { (5) \& (6) mean }=0.003]\end{array}$ & $\begin{array}{c}-0.0008 \\
(0.0006)\end{array}$ & $\begin{array}{c}0.0008 \\
{[-0.0022} \\
0.0045]\end{array}$ & $\begin{array}{c}-0.001 \\
(0.00004)\end{array}$ & $\begin{array}{c}-0.0003 \\
{[-0.002} \\
0.002]\end{array}$ & $\begin{array}{c}-0.0007 \\
(0.00003)\end{array}$ & $\begin{array}{c}-0.0062 \\
{[-0.01} \\
0.01]\end{array}$ \\
\hline $\begin{array}{c}\text { In jail } \\
{[(1) \&(2) \text { mean }=0.004} \\
(3) \&(4) \text { mean }=0.003 \\
(5) \&(6) \text { mean }=0.004]\end{array}$ & $\begin{array}{c}-0.0009 \\
(0.00002)\end{array}$ & $\begin{array}{c}0.0016 \\
{[-0.0016} \\
0.0050]\end{array}$ & $\begin{array}{c}-0.0009 \\
(0.00003)\end{array}$ & $\begin{array}{c}0.0005 \\
{[-0.0013,} \\
0.0023]\end{array}$ & $\begin{array}{c}-0.0009 \\
(0.00003)\end{array}$ & $\begin{array}{c}0.0075 \\
{[-0.010} \\
0.010]\end{array}$ \\
\hline White females ages 25-54: & & & & & & \\
\hline $\begin{array}{c}\text { Divorced } \\
{[(1) \&(2) \text { mean }=0.064} \\
(3) \&(4) \text { mean }=0.064 \\
(5) \&(6) \text { mean }=0.064]\end{array}$ & $\begin{array}{c}-0.0008 \\
(0.00009)\end{array}$ & $\begin{array}{c}0.0062 \\
{[-0.0009} \\
0.0164]\end{array}$ & $\begin{array}{l}-0.0014 \\
(0.0002)\end{array}$ & $\begin{array}{c}-0.0031 \\
{[-0.0102} \\
0.0047]\end{array}$ & $\begin{array}{c}-0.0003 \\
(0.0001)\end{array}$ & $\begin{array}{c}0.0168 \\
{[-0.0049} \\
0.0200]\end{array}$ \\
\hline $\begin{array}{l}\text { In mental institution } \\
{[(1) \&(2) \text { mean }=0.002} \\
(3) \&(4) \text { mean }=0.002 \\
\text { (5) \& (6) mean }=0.002]\end{array}$ & $\begin{array}{c}-0.0006 \\
(0.00003)\end{array}$ & $\begin{array}{c}-0.0010 \\
{[-0.0026} \\
0.0014]\end{array}$ & $\begin{array}{c}-0.0007 \\
(0.00004)\end{array}$ & $\begin{array}{c}-0.0012 \\
{[-0.0028} \\
0.0011]\end{array}$ & $\begin{array}{c}-0.0005 \\
(0.00003)\end{array}$ & $\begin{array}{c}-0.00002 \\
{[-0.004} \\
0.004]\end{array}$ \\
\hline
\end{tabular}

Notes: The data use the U.S. Census extracts from 1960, 1970 and 1980. The estimates use samples of white males and females aged 25 to 54; the estimates in columns (3), (4) are derived from individuals born in states whose average teacher pay is above the population-weighted median value, and the estimates in columns (5), (6) are derived from individuals born in states whose average teacher pay is below the population-weighted median value. All regressions include year-of-birth and state-of-birth indicator variables, and estimates in columns (2), (4), and (6) also contain region-by-year-of-birth indicator variables and school quality measures. 
Appendix Table 1: State Averages, Ranks and Cumulative Frequencies of Relative Teacher Salary

\begin{tabular}{|c|c|c|c|c|c|}
\hline \multicolumn{3}{|c|}{ Above-Median States } & \multicolumn{3}{|c|}{ Below-Median States } \\
\hline State & $\begin{array}{c}\text { Average } \\
\text { Teacher Salary }\end{array}$ & $\begin{array}{c}\text { Average } \\
\text { Teacher Salary } \\
\text { Cumulative } \\
\text { Frequency }\end{array}$ & State & $\begin{array}{c}\text { Average } \\
\text { Teacher Salary }\end{array}$ & $\begin{array}{c}\text { Average } \\
\text { Teacher Salary } \\
\text { Cumulative } \\
\text { Frequency }\end{array}$ \\
\hline D.C & 1.482 & 100 & Minnesota & 1.001 & 46.59 \\
\hline New York & 1.360 & 99.67 & Colorado & 0.995 & 44.25 \\
\hline Massachusetts & 1.270 & 90.51 & Wisconsin & 0.990 & 43.28 \\
\hline California & 1.230 & 87.27 & Nevada & 0.977 & 40.63 \\
\hline Rhode Island & 1.227 & 82.36 & Wyoming & 0.969 & 40.52 \\
\hline Maryland & 1.214 & 81.82 & Louisiana & 0.962 & 40.31 \\
\hline New Jersey & 1.172 & 80.56 & Montana & 0.956 & 38.79 \\
\hline Pennsylvania & 1.142 & 77.68 & Texas & 0.933 & 38.33 \\
\hline Arizona & 1.121 & 69.90 & Michigan & 0.933 & 32.94 \\
\hline New Mexico & 1.110 & 69.46 & Virginia & 0.925 & 28.62 \\
\hline Connecticut & 1.101 & 68.91 & Idaho & 0.924 & 26.65 \\
\hline Florida & 1.092 & 67.63 & South Carolina & 0.921 & 26.16 \\
\hline Washington & 1.085 & 66.43 & Missouri & 0.904 & 25.04 \\
\hline North Carolina & 1.083 & 65.07 & Iowa & 0.879 & 22.24 \\
\hline Illinois & 1.078 & 62.45 & Vermont & 0.876 & 20.12 \\
\hline New Hampshire & 1.068 & 56.77 & Oklahoma & 0.875 & 19.81 \\
\hline Delaware & 1.066 & 56.39 & Georgia & 0.874 & 17.86 \\
\hline Utah & 1.052 & 56.20 & Kansas & 0.860 & 15.83 \\
\hline Indiana & 1.036 & 55.56 & Tennessee & 0.859 & 14.33 \\
\hline Oregon & 1.012 & 52.76 & West Virginia & 0.845 & 11.95 \\
\hline \multirow[t]{8}{*}{ Ohio } & 1.003 & 51.94 & Alabama & 0.843 & 10.17 \\
\hline & & & South Dakota & 0.840 & 8.26 \\
\hline & & & Nebraska & 0.811 & 7.68 \\
\hline & & & Maine & 0.809 & 6.53 \\
\hline & & & North Dakota & 0.807 & 5.82 \\
\hline & & & Arkansas & 0.801 & 5.17 \\
\hline & & & Kentucky & 0.795 & 3.70 \\
\hline & & & Mississippi & 0.732 & 1.09 \\
\hline
\end{tabular}


Appendix Table 1B: State Averages, Ranks and Cumulative Frequencies of Relative Pupil-Teacher Ratio

\begin{tabular}{|c|c|c|c|c|c|}
\hline \multicolumn{3}{|c|}{ Smaller-than-Median States } & \multicolumn{3}{|c|}{ "Larger-than-Median States } \\
\hline State & $\begin{array}{l}\text { Average Pupil- } \\
\text { Teacher Ratio }\end{array}$ & $\begin{array}{c}\text { Average Pupil- } \\
\text { Teacher Ratio } \\
\text { Cumulative } \\
\text { Frequency }\end{array}$ & State & $\begin{array}{l}\text { Average Pupil- } \\
\text { Teacher Ratio }\end{array}$ & $\begin{array}{c}\text { Average Pupil- } \\
\text { Teacher Ratio } \\
\text { Cumulative } \\
\text { Frequency }\end{array}$ \\
\hline South Dakota & 17.68 & 0.59 & West Virginia & 26.90 & 52.49 \\
\hline North Dakota & 18.29 & 1.23 & Missouri & 27.03 & 55.29 \\
\hline Nebraska & 19.97 & 2.38 & New Mexico & 27.11 & 55.84 \\
\hline Montana & 20.03 & 2.85 & Ohio & 27.16 & 61.19 \\
\hline Iowa & 20.83 & 4.96 & Arizona & 27.33 & 61.63 \\
\hline Wyoming & 20.87 & 5.18 & California & 27.43 & 66.54 \\
\hline Kansas & 20.95 & 6.68 & D.C. & 27.66 & 66.54 \\
\hline Vermont & 22.60 & 6.99 & Pennsylvania & 27.82 & 74.65 \\
\hline Oregon & 23.28 & 7.81 & Oklahoma & 28.24 & 79.40 \\
\hline Minnesota & 23.86 & 10.15 & Utah & 28.54 & 80.04 \\
\hline New Hampshire & 23.86 & 10.53 & Virginia & 28.67 & 82.01 \\
\hline Wisconsin & 23.98 & 13.18 & Maryland & 28.70 & 83.26 \\
\hline Colorado & 24.05 & 14.15 & Louisiana & 29.39 & 84.77 \\
\hline Delaware & 24.18 & 14.33 & Kentucky & 29.72 & 87.37 \\
\hline Nevada & 24.23 & 14.44 & Tennessee & 30.42 & 89.75 \\
\hline Maine & 24.42 & 15.15 & South Carolina & 30.58 & 90.87 \\
\hline New Jersey & 24.68 & 18.04 & Georgia & 30.77 & 92.90 \\
\hline New York & 24.76 & 27.20 & North Carolina & 31.34 & 95.52 \\
\hline Massachusetts & 25.13 & 30.44 & Alabama & 31.90 & 97.43 \\
\hline Rhode Island & 25.27 & 30.99 & Arkansas & 32.35 & 98.91 \\
\hline Illinois & 25.50 & 36.67 & Mississippi & 33.74 & 100 \\
\hline Idaho & 25.77 & 37.16 & & & \\
\hline Connecticut & 25.86 & 38.44 & & & \\
\hline Michigan & 26.52 & 42.77 & & & \\
\hline Washington & 26.70 & 44.13 & & & \\
\hline Texas & 26.79 & 49.51 & & & \\
\hline Florida & 26.79 & 50.71 & & & \\
\hline
\end{tabular}


Appendix Table 1C: State Averages, Ranks and Cumulative Frequencies of Term Length

\begin{tabular}{|c|c|c|c|c|c|}
\hline \multicolumn{3}{|c|}{ Longer-than-Median Term Lengths } & \multicolumn{3}{|c|}{ "Shorter-than-Median States } \\
\hline State & $\begin{array}{c}\text { Average Term } \\
\text { Length }\end{array}$ & $\begin{array}{c}\text { Average Term } \\
\text { Length } \\
\text { Cumulative } \\
\text { Frequency }\end{array}$ & State & $\begin{array}{l}\text { Average Term } \\
\text { Length }\end{array}$ & $\begin{array}{c}\text { Average Term } \\
\text { Length } \\
\text { Cumulative } \\
\text { Frequency }\end{array}$ \\
\hline Illinois & 183.7 & 100 & New Hampshire & 176.9 & 45.27 \\
\hline Maryland & 183.6 & 94.32 & California & 176.9 & 44.89 \\
\hline New Jersey & 182.9 & 93.07 & Nebraska & 176.8 & 39.98 \\
\hline New York & 182.2 & 90.18 & Oregon & 176.6 & 38.83 \\
\hline Pennsylvania & 181.7 & 81.02 & Colorado & 176.1 & 38.01 \\
\hline Delaware & 181.0 & 73.24 & Wyoming & 175.9 & 37.04 \\
\hline Connecticut & 180.8 & 73.06 & South Dakota & 175.4 & 36.83 \\
\hline Rhode Island & 180.4 & 71.77 & Florida & 175.3 & 36.24 \\
\hline Michigan & 180.2 & 71.23 & Utah & 174.8 & 35.04 \\
\hline Missouri & 179.3 & 66.90 & North Dakota & 174.5 & 34.40 \\
\hline Maine & 179.2 & 64.10 & Minnesota & 174.1 & 33.75 \\
\hline Massachusetts & 178.6 & 63.38 & Oklahoma & 173.9 & 31.41 \\
\hline Wisconsin & 178.5 & 60.15 & Vermont & 173.4 & 29.45 \\
\hline New Mexico & 178.4 & 57.50 & Idaho & 173.1 & 29.15 \\
\hline Washington & 178.4 & 56.96 & West Virginia & 172.9 & 28.65 \\
\hline Ohio & 178.2 & 55.60 & Kansas & 172.8 & 26.87 \\
\hline \multirow[t]{2}{*}{$\mathrm{DC}$} & 177.8 & 50.25 & North Carolina & 172.5 & 25.37 \\
\hline & & & Indiana & 172.2 & 22.75 \\
\hline Iowa & 177.7 & 49.92 & Louisiana & 172.0 & 19.97 \\
\hline Montana & 177.4 & 47.80 & Texas & 170.8 & 18.43 \\
\hline Nevada & 177.1 & 47.34 & Georgia & 170.1 & 13.05 \\
\hline \multirow[t]{7}{*}{ Virginia } & 177.0 & 47.23 & Tennessee & 170.0 & 11.02 \\
\hline & & & Arizona & 169.9 & 8.65 \\
\hline & & & South Carolina & 168.8 & 8.20 \\
\hline & & & Kentucky & 165.9 & 7.08 \\
\hline & & & Alabama & 165.1 & 4.48 \\
\hline & & & Arkansas & 162.9 & 2.57 \\
\hline & & & Mississippi & 155.9 & 1.09 \\
\hline
\end{tabular}


Appendix Table 2: 2SLS Estimates of the Returns to Schooling with the Child Labor Instrument for the Pooled Sample and Subsamples Divided by Teacher Pay

\begin{tabular}{|c|c|c|c|c|c|c|c|c|c|c|c|c|}
\hline & \multicolumn{6}{|c|}{ White Males Ages 25-54 } & \multicolumn{6}{|c|}{ All Whites Ages 25-54 } \\
\hline & \multicolumn{2}{|c|}{ Pooled } & \multicolumn{2}{|c|}{ Higher than Median } & \multicolumn{2}{|c|}{$\begin{array}{l}\text { Lower than } \\
\text { Median }\end{array}$} & \multicolumn{2}{|c|}{ Pooled } & \multicolumn{2}{|c|}{ Higher than Median } & \multicolumn{2}{|c|}{ Lower than Median } \\
\hline & (1) & (2) & (3) & (4) & (5) & (6) & (7) & (8) & (9) & $(10)$ & $(11)$ & (12) \\
\hline 2SLS & $\begin{array}{c}0.076 \\
{[0.058,} \\
0.106]\end{array}$ & $\begin{array}{c}0.023 \\
{[-0.036} \\
0.060]\end{array}$ & $\begin{array}{c}0.071 \\
{[0.043,} \\
0.110]\end{array}$ & $\begin{array}{c}0.086 \\
{[0.036,} \\
0.135]\end{array}$ & $\begin{array}{c}0.105 \\
{[0.093} \\
0.154]\end{array}$ & $\begin{array}{c}-0.053 \\
{[-0.050} \\
0.009]\end{array}$ & $\begin{array}{c}0.077 \\
{[0.067,} \\
0.104]\end{array}$ & $\begin{array}{c}0.002 \\
{[-0.055} \\
0.021]\end{array}$ & $\begin{array}{c}0.077 \\
{[0.053,} \\
0.101]\end{array}$ & $\begin{array}{c}0.073 \\
{[0.046,} \\
0.105]\end{array}$ & $\begin{array}{c}0.102 \\
{[0.079,} \\
0.130]\end{array}$ & $\begin{array}{c}-0.058 \\
{[-0.050} \\
-0.010]\end{array}$ \\
\hline $\begin{array}{l}\text { First } \\
\text { Stage }\end{array}$ & & & & & & & & & & & & \\
\hline CL7 & $\begin{array}{c}0.137 \\
(0.025)\end{array}$ & $\begin{array}{c}0.104 \\
(0.019)\end{array}$ & $\begin{array}{c}0.249 \\
(0.043)\end{array}$ & $\begin{array}{c}0.094 \\
(0.037)\end{array}$ & $\begin{array}{c}0.104 \\
(0.026)\end{array}$ & $\begin{array}{c}0.121 \\
(0.023)\end{array}$ & $\begin{array}{c}0.128 \\
(0.020)\end{array}$ & $\begin{array}{c}0.075 \\
(0.015)\end{array}$ & $\begin{array}{c}0.291 \\
(0.040)\end{array}$ & $\begin{array}{c}0.070 \\
(0.031)\end{array}$ & $\begin{array}{c}0.069 \\
(0.020)\end{array}$ & $\begin{array}{c}0.085 \\
(0.017)\end{array}$ \\
\hline CL8 & $\begin{array}{c}0.183 \\
(0.022)\end{array}$ & $\begin{array}{c}0.090 \\
(0.017)\end{array}$ & $\begin{array}{c}0.246 \\
(0.033)\end{array}$ & $\begin{array}{c}0.109 \\
(0.027)\end{array}$ & $\begin{array}{c}0.167 \\
(0.029)\end{array}$ & $\begin{array}{c}0.046 \\
(0.026)\end{array}$ & $\begin{array}{c}0.154 \\
(0.018)\end{array}$ & $\begin{array}{c}0.068 \\
(0.013)\end{array}$ & $\begin{array}{c}0.260 \\
(0.030)\end{array}$ & $\begin{array}{c}0.087 \\
(0.022)\end{array}$ & $\begin{array}{c}0.122 \\
(0.023)\end{array}$ & $\begin{array}{c}0.024 \\
(0.019)\end{array}$ \\
\hline CL9 & $\begin{array}{c}0.337 \\
(0.028)\end{array}$ & $\begin{array}{c}0.164 \\
(0.020)\end{array}$ & $\begin{array}{c}0.480 \\
(0.048)\end{array}$ & $\begin{array}{c}0.221 \\
(0.040)\end{array}$ & $\begin{array}{c}0.297 \\
(0.031)\end{array}$ & $\begin{array}{c}0.123 \\
(0.026)\end{array}$ & $\begin{array}{c}0.323 \\
(0.024)\end{array}$ & $\begin{array}{c}0.158 \\
(0.017)\end{array}$ & $\begin{array}{c}0.520 \\
(0.046)\end{array}$ & $\begin{array}{c}0.199 \\
(0.034)\end{array}$ & $\begin{array}{c}0.264 \\
(0.027)\end{array}$ & $\begin{array}{c}0.118 \\
(0.020)\end{array}$ \\
\hline $\begin{array}{l}\text { F- } \\
\text { test }\end{array}$ & 54.4 & 22.0 & 41.1 & 18.5 & 31.8 & 14.7 & 65.2 & 33.4 & 50.3 & 23.6 & 36.0 & 20.6 \\
\hline $\mathrm{N}$ & $2,166,387$ & $2,166,387$ & $1,174,871$ & $1,174,871$ & 991,516 & 991,516 & $3,608,223$ & $3,608,223$ & $1,992,397$ & $1,992,397$ & $1,687,826$ & $1,687,826$ \\
\hline
\end{tabular}

Notes: The data use the U.S. Census extracts from 1960, 1970 and 1980. The estimates in columns (1) to (6) use a sample of white males aged 40 to 49, and the estimates in columns (7) to (12) use a sample of white males aged 25 to 54. The estimates in columns (3), (4), (9) and (10) are derived from individuals born in states whose average teacher pay is above the population-weighted median value, and the estimates in columns (5), (6), (11) and (12) are derived individuals born in states whose average teacher pay is below the population-weighted median value. OLS and 2SLS estimates of the returns to schooling are in the first two rows of the table, and the Moreira confidence interval for the 2SLS estimates are listed in brackets underneath the 2SLS estimates. The key instruments used in the first stage regression are three child labor indicators, indicating seven, eight or nine years of required schooling in a state for a particular birth cohort before it is permissible to work; these coefficients are listed in the rows entitled CL7, CL8 and CL9. All regressions include year-of-birth and state-of-birth indicator variables, and estimates in evennumbered columns also contain region-by-year-of-birth indicator variables. 
Appendix Table 3: 2SLS Estimates of the Returns to Schooling with the Child Labor Instrument

for the Pooled Sample and Subsamples Divided by Teacher Pay

\begin{tabular}{|c|c|c|c|c|c|c|c|c|c|c|c|c|}
\hline & \multicolumn{6}{|c|}{ PAll Whites Ages 25-54 } & \multicolumn{6}{|c|}{ All Whites Ages 25-54 } \\
\hline & \multicolumn{2}{|c|}{ Pooled } & \multicolumn{2}{|c|}{ Higher than Median } & \multicolumn{2}{|c|}{ Lower than Median } & \multicolumn{2}{|c|}{ Pooled } & \multicolumn{2}{|c|}{ Higher than Median } & \multicolumn{2}{|c|}{ Lower than Median } \\
\hline & $\begin{array}{l}\text { Non- } \\
\text { South }\end{array}$ & South & $\begin{array}{l}\text { Non- } \\
\text { South }\end{array}$ & South & $\begin{array}{l}\text { Non- } \\
\text { South }\end{array}$ & South & $\begin{array}{c}\text { Non- } \\
\text { Migrant }\end{array}$ & Migrant & $\begin{array}{c}\text { Non- } \\
\text { Migrant }\end{array}$ & Migrant & $\begin{array}{c}\text { Non- } \\
\text { Migrant }\end{array}$ & Migrant \\
\hline & (1) & (2) & (3) & (4) & (5) & (6) & (7) & (8) & (9) & $(10)$ & (11) & $(12)$ \\
\hline 2SLS & -0.005 & -0.022 & 0.044 & 0.254 & 0.082 & -0.077 & -0.058 & 0.089 & 0.060 & 0.148 & -0.110 & 0.051 \\
\hline & {$[-0.055$,} & {$[-0.089$,} & {$[0.009$,} & {$[0.150$} & {$[-0.010$} & {$[-0.150$} & {$[-0.108$,} & {$[0.042$} & {$[0.015$,} & {$[0.111$} & {$[-0.190$,} & {$[0.007$} \\
\hline & $0.027]$ & $0.021]$ & $0.071]$ & $0.358]$ & $0.130]$ & $-0.030]$ & $-0.026]$ & $0.137]$ & $0.105]$ & $0.189]$ & $-0.029]$ & $0.084]$ \\
\hline \multirow{2}{*}{\multicolumn{13}{|c|}{$\begin{array}{l}\text { First } \\
\text { Stage }\end{array}$}} \\
\hline & & & & & & & & & & & & \\
\hline CL7 & $\begin{array}{c}0.217 \\
(0.034)\end{array}$ & $\begin{array}{c}0.090 \\
(0.019)\end{array}$ & $\begin{array}{c}0.392 \\
(0.045)\end{array}$ & $\begin{array}{l}-0.095 \\
(0.089)\end{array}$ & $\begin{array}{l}-0.077 \\
(0.037)\end{array}$ & $\begin{array}{c}0.103 \\
(0.019)\end{array}$ & $\begin{array}{c}0.048 \\
(0.017)\end{array}$ & $\begin{array}{c}0.175 \\
(0.023)\end{array}$ & $\begin{array}{c}0.061 \\
(0.035)\end{array}$ & $\begin{array}{c}0.197 \\
(0.045)\end{array}$ & $\begin{array}{c}0.039 \\
(0.021)\end{array}$ & $\begin{array}{c}0.168 \\
(0.026)\end{array}$ \\
\hline CL8 & $\begin{array}{c}0.184 \\
(0.026)\end{array}$ & $\begin{array}{c}0.020 \\
(0.022)\end{array}$ & $\begin{array}{c}0.298 \\
(0.033)\end{array}$ & $\begin{array}{c}-0.111 \\
(0.089)\end{array}$ & $\begin{array}{l}-0.074 \\
(0.035)\end{array}$ & $\begin{array}{c}0.028 \\
(0.022)\end{array}$ & $\begin{array}{c}0.063 \\
(0.014)\end{array}$ & $\begin{array}{c}0.145 \\
(0.021)\end{array}$ & $\begin{array}{c}0.067 \\
(0.024)\end{array}$ & $\begin{array}{c}0.253 \\
(0.034)\end{array}$ & $\begin{array}{c}0.078 \\
(0.022)\end{array}$ & $\begin{array}{l}-0.027 \\
(0.028)\end{array}$ \\
\hline CL9 & $\begin{array}{c}0.360 \\
(0.033)\end{array}$ & $\begin{array}{c}0.132 \\
(0.023)\end{array}$ & $\begin{array}{c}0.558 \\
(0.049)\end{array}$ & $\begin{array}{c}0.084 \\
(0.098)\end{array}$ & $\begin{array}{c}0.015 \\
(0.035)\end{array}$ & $\begin{array}{c}0.124 \\
(0.023)\end{array}$ & $\begin{array}{c}0.151 \\
(0.019)\end{array}$ & $\begin{array}{c}0.186 \\
(0.025)\end{array}$ & $\begin{array}{c}0.192 \\
(0.038)\end{array}$ & $\begin{array}{c}0.279 \\
(0.047)\end{array}$ & $\begin{array}{c}0.148 \\
(0.024)\end{array}$ & $\begin{array}{c}0.111 \\
(0.029)\end{array}$ \\
\hline F-test & 47.8 & 16.1 & 47.0 & 8.7 & 7.5 & 15.5 & 26.7 & 22.0 & 17.9 & 30.5 & 13.2 & 25.3 \\
\hline $\mathrm{N}$ & $2,566,127$ & $1,114,096$ & $1,782,054$ & 322,663 & 784,073 & 903,753 & $2,320,750$ & $1,359,473$ & $1,313,309$ & 679,088 & $1,007,441$ & 680,385 \\
\hline
\end{tabular}

Notes: The data use a sample of white males and females aged 25 to 54 from the 1960, 1970 and 1980 U.S. Census extracts. Estimates in columns (7), (9) and (11) use a subsample of respondents from southern states; the estimates in columns (8), (10) and (12) use a subsample of respondents from non-southern states. The estimates in columns (3), (4), (9) and (10) are derived from individuals born in states whose average teacher pay is above the population-weighted median value, and the estimates in columns (5), (6), (11) and (12) are derived individuals born in states whose average teacher pay is below the population-weighted median value. OLS and 2SLS estimates of the returns to schooling are in the first two rows of the table, and the Moreira confidence interval for the 2SLS estimates are listed in brackets underneath the 2SLS estimates. The key instruments used in the first stage regression are three child labor indicators, indicating seven, eight or nine years of required schooling in a state for a particular birth cohort before it is permissible to work; these coefficients are listed in the rows entitled CL7, CL8 and CL9. All regressions include year-of-birth and state-of-birth indicator variables, and estimates in columns (2), (4), (6), and (7) through (12) also contain region-by-year-of-birth indicator variables. 
Appendix Table 4: OLS and 2SLS Estimates of the Returns to Schooling for Pooled Sample and Subsamples Divided by Term Length

\begin{tabular}{|c|c|c|c|c|c|c|c|c|c|c|c|c|}
\hline & \multicolumn{6}{|c|}{ White Males Ages 25-54 } & \multicolumn{6}{|c|}{ All Whites Ages 25-54 } \\
\hline & \multicolumn{2}{|c|}{ Pooled } & \multicolumn{2}{|c|}{$\begin{array}{c}\text { Terms Longer } \\
\text { than Median }\end{array}$} & \multicolumn{2}{|c|}{$\begin{array}{l}\text { Terms Shorter } \\
\text { than Median }\end{array}$} & \multicolumn{2}{|c|}{ Pooled } & \multicolumn{2}{|c|}{$\begin{array}{c}\text { Terms Longer } \\
\text { than Median }\end{array}$} & \multicolumn{2}{|c|}{$\begin{array}{c}\text { Terms Shorter } \\
\text { than Median }\end{array}$} \\
\hline & $(1)$ & $(2)$ & (3) & $(4)$ & (5) & $(6)$ & $(7)$ & $(8)$ & (9) & $(10)$ & $(11)$ & $(12)$ \\
\hline OLS & $\begin{array}{c}0.063 \\
(0.0004)\end{array}$ & $\begin{array}{c}0.063 \\
(0.0004)\end{array}$ & $\begin{array}{c}0.062 \\
(0.0006)\end{array}$ & $\begin{array}{c}0.062 \\
(0.0006)\end{array}$ & $\begin{array}{c}0.065 \\
(0.0004)\end{array}$ & $\begin{array}{c}0.064 \\
(0.0005)\end{array}$ & $\begin{array}{c}0.068 \\
(0.0003)\end{array}$ & $\begin{array}{c}0.068 \\
(0.0003)\end{array}$ & $\begin{array}{c}0.067 \\
(0.0004)\end{array}$ & $\begin{array}{c}0.067 \\
(0.0004)\end{array}$ & $\begin{array}{c}0.069 \\
(0.0003)\end{array}$ & $\begin{array}{c}0.069 \\
(0.0004)\end{array}$ \\
\hline 2SLS & $\begin{array}{c}0.097 \\
{[0.080,} \\
0.117]\end{array}$ & $\begin{array}{c}-0.014 \\
{[-0.066} \\
0.021]\end{array}$ & $\begin{array}{c}0.017 \\
{[-0.008} \\
0.042]\end{array}$ & $\begin{array}{c}0.035 \\
{[0.004,} \\
0.061]\end{array}$ & $\begin{array}{c}0.108 \\
{[0.089,} \\
0.128]\end{array}$ & $\begin{array}{c}-0.024 \\
{[-0.125} \\
0.077]\end{array}$ & $\begin{array}{c}0.105 \\
{[0.083,} \\
0.123]\end{array}$ & $\begin{array}{c}-0.003 \\
{[-0.058} \\
0.016]\end{array}$ & $\begin{array}{c}0.004 \\
{[-0.016} \\
0.026]\end{array}$ & $\begin{array}{c}0.020 \\
{[-0.010} \\
0.033]\end{array}$ & $\begin{array}{c}0.134 \\
{[0.115,} \\
0.153]\end{array}$ & $\begin{array}{c}0.013 \\
{[-0.067} \\
0.092]\end{array}$ \\
\hline RS7 & $\begin{array}{c}0.097 \\
(0.036)\end{array}$ & $\begin{array}{c}0.047 \\
(0.027)\end{array}$ & $\begin{array}{c}0.026 \\
(0.044)\end{array}$ & $\begin{array}{c}0.033 \\
(0.040)\end{array}$ & $\begin{array}{c}0.129 \\
(0.047)\end{array}$ & $\begin{array}{c}0.051 \\
(0.036)\end{array}$ & $\begin{array}{c}0.079 \\
(0.033)\end{array}$ & $\begin{array}{c}0.029 \\
(0.022)\end{array}$ & $\begin{array}{c}0.026 \\
(0.036)\end{array}$ & $\begin{array}{c}0.012 \\
(0.031)\end{array}$ & $\begin{array}{c}0.112 \\
(0.040)\end{array}$ & $\begin{array}{c}0.045 \\
(0.028)\end{array}$ \\
\hline RS8 & $\begin{array}{c}0.268 \\
(0.028)\end{array}$ & $\begin{array}{c}0.135 \\
(0.024)\end{array}$ & $\begin{array}{c}0.283 \\
(0.039)\end{array}$ & $\begin{array}{c}0.257 \\
(0.038)\end{array}$ & $\begin{array}{c}0.195 \\
(0.041)\end{array}$ & $\begin{array}{c}0.059 \\
(0.033)\end{array}$ & $\begin{array}{c}0.246 \\
(0.026)\end{array}$ & $\begin{array}{c}0.136 \\
(0.019)\end{array}$ & $\begin{array}{c}0.320 \\
(0.033)\end{array}$ & $\begin{array}{c}0.271 \\
(0.032)\end{array}$ & $\begin{array}{c}0.174 \\
(0.035)\end{array}$ & $\begin{array}{c}0.065 \\
(0.026)\end{array}$ \\
\hline RS9 & $\begin{array}{c}0.449 \\
(0.033)\end{array}$ & $\begin{array}{c}0.217 \\
(0.029)\end{array}$ & $\begin{array}{c}0.382 \\
(0.051)\end{array}$ & $\begin{array}{c}0.386 \\
(0.050)\end{array}$ & $\begin{array}{c}0.455 \\
(0.040)\end{array}$ & $\begin{array}{c}0.122 \\
(0.036)\end{array}$ & $\begin{array}{c}0.406 \\
(0.028)\end{array}$ & $\begin{array}{c}0.222 \\
(0.023)\end{array}$ & $\begin{array}{c}0.414 \\
(0.044)\end{array}$ & $\begin{array}{c}0.404 \\
(0.043)\end{array}$ & $\begin{array}{c}0.402 \\
(0.033)\end{array}$ & $\begin{array}{c}0.115 \\
(0.028)\end{array}$ \\
\hline $\mathrm{N}$ & $2,166,387$ & $2,166,387$ & $1,098,241$ & $1,098,241$ & $1,068,146$ & $1,068,146$ & $3,680,223$ & $3,680,223$ & $1,850,340$ & $1,850,340$ & $1,829,883$ & $1,829,883$ \\
\hline
\end{tabular}

Notes: The data use the U.S. Census extracts from 1960, 1970 and 1980. The estimates in columns (1) to (6) use a sample of white males aged 25 to 54, and the estimates in columns (7) to (12) use a sample of white respondents aged 25 to 54. The estimates in columns (3), (4), (9) and (10) are derived from individuals born in states whose average term length is greater than the population-weighted median value, and the estimates in columns (5), (6), (11) and (12) are derived individuals born in states whose average term length is shorter than the population-weighted median value. OLS and 2SLS estimates of the returns to schooling are in the first two rows of the table, and the Moreira confidence interval for the 2SLS estimates are listed in brackets underneath the 2SLS estimates. The key instruments used in the first stage regression are three required schooling dummies, indicating seven, eight or nine years of required schooling in a state for a particular birth cohort; these coefficients are listed in the rows entitled RS7, RS8 and RS9. All regressions include year-of-birth and state-of-birth indicator variables, and estimates in even-numbered columns also contain region-by-year-of-birth indicator variables. 
Appendix Table 5: OLS and 2SLS Estimates of the Returns to Schooling for Pooled Sample and Subsamples Divided by Term Length

\begin{tabular}{|c|c|c|c|c|c|c|c|c|c|c|c|c|}
\hline & \multicolumn{6}{|c|}{ "White Males Ages 25-54 } & \multicolumn{6}{|c|}{ All Whites Ages 25-54 } \\
\hline & \multicolumn{2}{|c|}{ Pooled } & \multicolumn{2}{|c|}{$\begin{array}{l}\text { Terms Longer } \\
\text { than Median }\end{array}$} & \multicolumn{2}{|c|}{$\begin{array}{c}\text { Terms Shorter } \\
\text { than Median }\end{array}$} & \multicolumn{2}{|c|}{ Pooled } & \multicolumn{2}{|c|}{$\begin{array}{c}\text { Terms Longer } \\
\text { than Median }\end{array}$} & \multicolumn{2}{|c|}{$\begin{array}{l}\text { Terms Shorter } \\
\text { than Median }\end{array}$} \\
\hline & (1) & $(2)$ & (3) & $(4)$ & (5) & $(6)$ & (7) & (8) & $(9)$ & $(10)$ & $(11)$ & $(12)$ \\
\hline 2SLS & 0.076 & 0.023 & 0.002 & 0.076 & 0.110 & 0.019 & 0.077 & 0.002 & 0.027 & 0.049 & 0.102 & 0.003 \\
\hline & {$[0.058$} & {$[-0.036$} & {$[-0.057$} & {$[0.010$} & {$[0.091$} & {$[-0.046$} & {$[0.067$} & {$[-0.055$} & {$[-0.006$} & {$[0.005$} & {$[0.086$} & {$[-0.045$} \\
\hline & $0.106]$ & $0.060]$ & $0.060]$ & $0.143]$ & $0.130]$ & $0.083]$ & $0.104]$ & $0.021]$ & $0.060]$ & $0.093]$ & $0.119]$ & $0.048]$ \\
\hline \multicolumn{13}{|l|}{$\begin{array}{l}\text { First } \\
\text { Stage }\end{array}$} \\
\hline & 0.137 & 0.104 & 0.129 & 0.060 & 0.139 & 0.123 & 0.128 & 0.075 & 0.182 & 0.060 & 0.106 & 0.089 \\
\hline CL7 & $(0.025)$ & $(0.019)$ & $(0.037)$ & $(0.035)$ & $(0.029)$ & $(0.022)$ & $(0.020)$ & $(0.015)$ & $(0.035)$ & $(0.031)$ & $(0.023)$ & $(0.017)$ \\
\hline & 0.183 & 0.090 & 0.156 & 0.095 & 0.146 & 0.042 & 0.154 & 0.068 & 0.194 & 0.093 & 0.116 & 0.024 \\
\hline CL8 & $(0.022)$ & $(0.017)$ & $(0.028)$ & $(0.026)$ & $(0.032)$ & $(0.025)$ & $(0.018)$ & $(0.013)$ & $(0.026)$ & $(0.022)$ & $(0.027)$ & $(0.019)$ \\
\hline$C I^{9}$ & 0.337 & 0.164 & 0.232 & 0.137 & 0.424 & 0.147 & 0.323 & 0.158 & 0.305 & 0.154 & 0.378 & 0.134 \\
\hline CLY & $(0.028)$ & $(0.020)$ & $(0.039)$ & $(0.037)$ & $(0.037)$ & $(0.026)$ & $(0.024)$ & $(0.017)$ & $(0.037)$ & $(0.032)$ & $(0.032)$ & $(0.021)$ \\
\hline $\begin{array}{l}\text { F- } \\
\text { test }\end{array}$ & 54.4 & 22.0 & 15.9 & 9.8 & 46.5 & 18.1 & 65.2 & 33.4 & 27.1 & 16.6 & 50.5 & 21.5 \\
\hline $\mathrm{N}$ & 2,166,387 & $2,166,387$ & $1,098,241$ & $1,098,241$ & $1,068,146$ & $1,068,146$ & $3,608,223$ & $3,608,223$ & $1,850,340$ & $1,850,340$ & $1,829,883$ & $1,829,883$ \\
\hline
\end{tabular}

Notes: The data use the U.S. Census extracts from 1960, 1970 and 1980. The estimates in columns (1) to (6) use a sample of white males aged 25 to 54, and the estimates in columns (7) to (12) use a sample of all white respondents aged 25 to 54 . The estimates in columns (3), (4), (9) and (10) are derived from individuals born in states whose average term length is greater than the population-weighted median value, and the estimates in columns (5), (6), (11) and (12) are derived individuals born in states whose average term length is less than the population-weighted median value. OLS and 2SLS estimates of the returns to schooling are in the first two rows of the table, and the Moreira confidence interval for the 2SLS estimates are listed in brackets underneath the 2SLS estimates. The key instruments used in the first stage regression are three child labor indicators, indicating seven, eight or nine years of required schooling in a state for a particular birth cohort before it is permissible to work; these coefficients are listed in the rows entitled CL7, CL8 and CL9. All regressions include year-of-birth and state-of-birth indicator variables, and estimates in even-numbered columns also contain region-by-year-of-birth indicator variables. 
Appendix Table 6: OLS and 2SLS Estimates of the Returns to Schooling for Pooled Sample and Subsamples Divided by Pupil-Teacher Ratio

\begin{tabular}{|c|c|c|c|c|c|c|c|c|c|c|c|c|}
\hline & \multicolumn{6}{|c|}{ White Males Ages 25-54 } & \multicolumn{6}{|c|}{ All Whites Ages 25-54 } \\
\hline & \multicolumn{2}{|c|}{ Pooled } & \multicolumn{2}{|c|}{$\begin{array}{c}\text { Smaller classes } \\
\text { than Median }\end{array}$} & \multicolumn{2}{|c|}{$\begin{array}{l}\text { Larger classes } \\
\text { than Median }\end{array}$} & \multicolumn{2}{|c|}{ Pooled } & \multicolumn{2}{|c|}{$\begin{array}{c}\text { Smaller classes } \\
\text { than Median }\end{array}$} & \multicolumn{2}{|c|}{$\begin{array}{c}\text { Larger classes } \\
\text { than Median }\end{array}$} \\
\hline & (1) & (2) & (3) & $(4)$ & (5) & (6) & (7) & (8) & (9) & $(10)$ & $(11)$ & (12) \\
\hline OLS & $\begin{array}{c}0.063 \\
(0.0004)\end{array}$ & $\begin{array}{c}0.063 \\
(0.0004)\end{array}$ & $\begin{array}{c}0.063 \\
(0.0006)\end{array}$ & $\begin{array}{c}0.063 \\
(0.0006)\end{array}$ & $\begin{array}{c}0.064 \\
(0.0005)\end{array}$ & $\begin{array}{c}0.063 \\
(0.0005)\end{array}$ & $\begin{array}{c}0.068 \\
(0.0003)\end{array}$ & $\begin{array}{c}0.068 \\
(0.0003)\end{array}$ & $\begin{array}{c}0.069 \\
(0.0004)\end{array}$ & $\begin{array}{c}0.069 \\
(0.0004)\end{array}$ & $\begin{array}{c}0.068 \\
(0.0003)\end{array}$ & $\begin{array}{c}0.068 \\
(0.0004)\end{array}$ \\
\hline 2SLS & $\begin{array}{c}0.097 \\
{[0.080,} \\
0.117]\end{array}$ & $\begin{array}{c}-0.014 \\
{[-0.066} \\
0.021]\end{array}$ & $\begin{array}{c}0.063 \\
{[0.050,} \\
0.112]\end{array}$ & $\begin{array}{c}-0.029 \\
{[-0.064} \\
0.004]\end{array}$ & $\begin{array}{c}0.114 \\
{[0.097,} \\
0.134]\end{array}$ & $\begin{array}{c}0.019 \\
{[-0.030} \\
0.098]\end{array}$ & $\begin{array}{c}0.105 \\
{[0.083,} \\
0.123]\end{array}$ & $\begin{array}{c}-0.003 \\
{[-0.058} \\
0.016]\end{array}$ & $\begin{array}{c}0.022 \\
{[-0.009} \\
0.052]\end{array}$ & $\begin{array}{c}-0.041 \\
{[-0.070} \\
-0.012]\end{array}$ & $\begin{array}{c}0.105 \\
{[0.093,} \\
0.128]\end{array}$ & $\begin{array}{c}0.031 \\
{[-0.028} \\
0.090]\end{array}$ \\
\hline RS7 & $\begin{array}{c}0.097 \\
(0.036)\end{array}$ & $\begin{array}{c}0.047 \\
(0.027)\end{array}$ & $\begin{array}{l}-0.023 \\
(0.068)\end{array}$ & $\begin{array}{l}-0.017 \\
(0.125)\end{array}$ & $\begin{array}{c}0.206 \\
(0.046)\end{array}$ & $\begin{array}{c}0.156 \\
(0.036)\end{array}$ & $\begin{array}{c}0.079 \\
(0.033)\end{array}$ & $\begin{array}{c}0.029 \\
(0.022)\end{array}$ & $\begin{array}{l}-0.217 \\
(0.057)\end{array}$ & $\begin{array}{l}-0.092 \\
(0.076)\end{array}$ & $\begin{array}{c}0.235 \\
(0.041)\end{array}$ & $\begin{array}{c}0.138 \\
(0.028)\end{array}$ \\
\hline RS8 & $\begin{array}{c}0.268 \\
(0.028)\end{array}$ & $\begin{array}{c}0.135 \\
(0.024)\end{array}$ & $\begin{array}{c}0.296 \\
(0.066)\end{array}$ & $\begin{array}{c}0.245 \\
(0.127)\end{array}$ & $\begin{array}{c}0.214 \\
(0.038)\end{array}$ & $\begin{array}{c}0.133 \\
(0.033)\end{array}$ & $\begin{array}{c}0.246 \\
(0.026)\end{array}$ & $\begin{array}{c}0.136 \\
(0.019)\end{array}$ & $\begin{array}{c}0.138 \\
(0.054)\end{array}$ & $\begin{array}{c}0.206 \\
(0.079)\end{array}$ & $\begin{array}{c}0.255 \\
(0.033)\end{array}$ & $\begin{array}{c}0.131 \\
(0.025)\end{array}$ \\
\hline RS9 & $\begin{array}{c}0.449 \\
(0.033)\end{array}$ & $\begin{array}{c}0.217 \\
(0.029)\end{array}$ & $\begin{array}{c}0.411 \\
(0.068)\end{array}$ & $\begin{array}{c}0.338 \\
(0.127)\end{array}$ & $\begin{array}{c}0.545 \\
(0.043)\end{array}$ & $\begin{array}{c}0.198 \\
(0.036)\end{array}$ & $\begin{array}{c}0.406 \\
(0.028)\end{array}$ & $\begin{array}{c}0.222 \\
(0.023)\end{array}$ & $\begin{array}{c}0.264 \\
(0.055)\end{array}$ & $\begin{array}{c}0.321 \\
(0.079)\end{array}$ & $\begin{array}{c}0.514 \\
(0.038)\end{array}$ & $\begin{array}{c}0.184 \\
(0.028)\end{array}$ \\
\hline $\mathrm{N}$ & $2,166,387$ & $2,166,387$ & $1,101,342$ & $1,101,342$ & $1,065,045$ & $1,065,045$ & $3,680,223$ & $3,680,223$ & $1,879,243$ & $1,879,243$ & $1,800,980$ & $1,800,980$ \\
\hline
\end{tabular}

Notes: The data use the U.S. Census extracts from 1960, 1970 and 1980. The estimates in columns (1) to (6) use a sample of white males aged 25 to 54, and the estimates in columns (7) to (12) use a sample of all white respondents aged 25 to 54 . The estimates in columns (3), (4), (9) and (10) are derived from individuals born in states whose average pupil-teacher class ratios are smaller than the population-weighted median value, and the estimates in columns (5), (6), (11) and (12) are derived individuals born in states whose average pupil-teacher class ratios are larger than the population-weighted median value. OLS and 2SLS estimates of the returns to schooling are in the first two rows of the table, and the Moreira confidence interval for the 2SLS estimates are listed in brackets underneath the 2SLS estimates. The key instruments used in the first stage regression are three required schooling dummies, indicating seven, eight or nine years of required schooling in a state for a particular birth cohort; these coefficients are listed in the rows entitled RS7, RS8 and RS9. All regressions include year-of-birth and state-of-birth indicator variables, and estimates in even-numbered columns also contain region-by-year-of-birth indicator variables. 
Appendix Table 7: OLS and 2SLS Estimates of the Returns to Schooling for Pooled Sample and Subsamples Divided by Pupil-Teacher Ratio

\begin{tabular}{|c|c|c|c|c|c|c|c|c|c|c|c|c|}
\hline & \multicolumn{6}{|c|}{ White Males Ages 25-54 } & \multicolumn{6}{|c|}{ All Whites Ages 25-54 } \\
\hline & \multicolumn{2}{|c|}{ Pooled } & \multicolumn{2}{|c|}{$\begin{array}{l}\text { Smaller classes } \\
\text { than Median }\end{array}$} & \multicolumn{2}{|c|}{$\begin{array}{l}\text { Larger classes } \\
\text { than Median }\end{array}$} & \multicolumn{2}{|c|}{ Pooled } & \multicolumn{2}{|c|}{$\begin{array}{c}\text { Smaller classes } \\
\text { than Median }\end{array}$} & \multicolumn{2}{|c|}{$\begin{array}{c}\text { Larger classes } \\
\text { than Median }\end{array}$} \\
\hline 2SLS & $\begin{array}{c}(1) \\
0.076 \\
{[0.058,} \\
0.106]\end{array}$ & $\begin{array}{c}(2) \\
0.023 \\
{[-0.036,} \\
0.060]\end{array}$ & $\begin{array}{c}(3) \\
0.092 \\
{[0.068} \\
0.139]\end{array}$ & $\begin{array}{c}(4) \\
0.040 \\
{[-0.012} \\
0.091]\end{array}$ & $\begin{array}{c}(5) \\
0.138 \\
{[0.127} \\
0.159]\end{array}$ & $\begin{array}{c}(6) \\
0.032 \\
{[-0.020,} \\
0.092]\end{array}$ & $\begin{array}{c}(7) \\
0.077 \\
{[0.067,} \\
0.104]\end{array}$ & $\begin{array}{c}(8) \\
0.002 \\
{[-0.055} \\
0.021]\end{array}$ & $\begin{array}{c}(9) \\
0.018 \\
{[-0.022} \\
0.058]\end{array}$ & $\begin{array}{c}(10) \\
-0.037 \\
{[-0.082,} \\
0.007]\end{array}$ & $\begin{array}{c}(11) \\
0.140 \\
{[0.126} \\
0.160]\end{array}$ & $\begin{array}{c}(12) \\
0.047 \\
{[-0.001} \\
0.094]\end{array}$ \\
\hline $\begin{array}{l}\text { First } \\
\text { Stage }\end{array}$ & & & & & & & & & & & & \\
\hline CL7 & $\begin{array}{c}0.137 \\
(0.025)\end{array}$ & $\begin{array}{c}0.104 \\
(0.019)\end{array}$ & $\begin{array}{c}0.143 \\
(0.042)\end{array}$ & $\begin{array}{c}0.148 \\
(0.041)\end{array}$ & $\begin{array}{c}0.229 \\
(0.029)\end{array}$ & $\begin{array}{c}0.118 \\
(0.028)\end{array}$ & $\begin{array}{c}0.128 \\
(0.020)\end{array}$ & $\begin{array}{c}0.075 \\
(0.015)\end{array}$ & $\begin{array}{c}0.125 \\
(0.034)\end{array}$ & $\begin{array}{c}0.101 \\
(0.032)\end{array}$ & $\begin{array}{c}0.200 \\
(0.026)\end{array}$ & $\begin{array}{c}0.065 \\
(0.022)\end{array}$ \\
\hline CL8 & $\begin{array}{c}0.183 \\
(0.022)\end{array}$ & $\begin{array}{c}0.090 \\
(0.017)\end{array}$ & $\begin{array}{c}0.248 \\
(0.039)\end{array}$ & $\begin{array}{c}0.190 \\
(0.041)\end{array}$ & $\begin{array}{c}0.034 \\
(0.026)\end{array}$ & $\begin{array}{l}-0.035 \\
(0.037)\end{array}$ & $\begin{array}{c}0.154 \\
(0.018)\end{array}$ & $\begin{array}{c}0.068 \\
(0.013)\end{array}$ & $\begin{array}{c}0.188 \\
(0.033)\end{array}$ & $\begin{array}{c}0.133 \\
(0.032)\end{array}$ & $\begin{array}{c}0.069 \\
(0.024)\end{array}$ & $\begin{array}{l}-0.062 \\
(0.029)\end{array}$ \\
\hline CL9 & $\begin{array}{c}0.337 \\
(0.028)\end{array}$ & $\begin{array}{c}0.164 \\
(0.020)\end{array}$ & $\begin{array}{c}0.269 \\
(0.042)\end{array}$ & $\begin{array}{c}0.226 \\
(0.042)\end{array}$ & $\begin{array}{c}0.479 \\
(0.039)\end{array}$ & $\begin{array}{c}0.145 \\
(0.030)\end{array}$ & $\begin{array}{c}0.323 \\
(0.024)\end{array}$ & $\begin{array}{c}0.158 \\
(0.017)\end{array}$ & $\begin{array}{c}0.277 \\
(0.035)\end{array}$ & $\begin{array}{c}0.202 \\
(0.033)\end{array}$ & $\begin{array}{c}0.425 \\
(0.035)\end{array}$ & $\begin{array}{c}0.115 \\
(0.025)\end{array}$ \\
\hline $\begin{array}{l}\text { F- } \\
\text { test }\end{array}$ & 54.4 & 22.0 & 25.2 & 14.5 & 68.2 & 18.6 & 65.2 & 33.4 & 31.7 & 24.1 & 56.9 & 20.3 \\
\hline $\mathrm{N}$ & $2,166,387$ & $2,166,387$ & $1,101,342$ & $1,101,342$ & $1,065,045$ & $1,065,045$ & $3,608,223$ & $3,608,223$ & $1,879,243$ & $1,879,243$ & $1,800,980$ & $1,800,980$ \\
\hline
\end{tabular}

Notes: The data use the U.S. Census extracts from 1960, 1970 and 1980. The estimates in columns (1) to (6) use a sample of white males aged 25 to 54, and the estimates in columns (7) to (12) use a sample of all white respondents aged 25 to 54 . The estimates in columns (3), (4), (9) and (10) are derived from individuals born in states whose average pupil-teacher class ratios are smaller than the population-weighted median value, and the estimates in columns (5), (6), (11) and (12) are derived individuals born in states whose average pupil-teacher class ratios are larger than the population-weighted median value. OLS and 2SLS estimates of the returns to schooling are in the first two rows of the table, and the Moreira confidence interval for the 2SLS estimates are listed in brackets underneath the 2SLS estimates. The key instruments used in the first stage regression are three child labor indicators, indicating seven, eight or nine years of required schooling in a state for a particular birth cohort before it is permissible to work; these coefficients are listed in the rows entitled CL7, CL8 and CL9. All regressions include year-of-birth and state-of-birth indicator variables, and estimates in even-numbered columns also contain region-by-year-of-birth indicator variables. 